\title{
Conservation of Resources Theory by Stevan E. Hobfoll and prediction of alcohol DEPENDENT PERSONS' ABSTINENCE
}

\section{Teoria Zachowania Zasobów Stevana E. Hobfolla A PRZEWIDYWANIE UTRZYMYWANIA ABSTYNENCJI PRZEZ OSOBY UZALEŻNIONE OD ALKOHOLU}

\author{
Robert Modrzyński \\ Department of Clinical Psychology and Neuropsychology, Maria Curie-Skłodowska University in Lublin, Poland \\ Zakład Psychologii Klinicznej i Neuropsychologii, Uniwersytet Marii Curie-Skłodowskiej (UMSC) w Lublinie, Polska
}

Alcohol Drug Addict 2018; 31 (2): 147-170

DOI: https://doi.org/10.5114/ain.2018.79992

\begin{abstract}
Introduction: Stevan E. Hobfoll's Conservation of Resources Theory (COR) may be an alternative concept of alcohol dependence understanding. COR is based on the premise that human activity is focused on gaining, maintaining and protecting resources. The gain or loss of resources is fundamental to the quality of life and motivation for change. In this perspective, loss of resources, or lack of opportunity to gain them, explain the high percentage of relapsing patients. The aim of the study is to answer whether maintaining abstinence be predicted, what kind of resources play a key role in the several steps of recovery and to whom it is worth applying the total abstinence-based model on the one hand and the harm reduction approach on the other.
\end{abstract}

\section{Streszczenie}

Wprowadzenie: Teoria Zachowania Zasobów Stevana E. Hobfolla (COR) może stanowić alternatywna koncepcję rozumienia uzależnienia od alkoholu. Teoria ta opiera się na założeniu, że aktywność człowieka jest skoncentrowana na zdobywaniu, utrzymywaniu i ochronie zasobów. Ich zdobywanie lub utrata ma fundamentalne znaczenie dla jakości życia i stanowi źródło motywacji do zmian. Z perspektywy COR utrata zasobów lub brak możliwości ich pozyskania tłumaczy wysoki odsetek osób łamiących abstynencję. Celem pracy jest odpowiedź na trzy pytania: czy można przewidywać utrzymywanie abstynencji, jakie zasoby odgrywają kluczową rolę na poszczególnych etapach zdrowienia oraz którym pacjentom warto proponować model terapii oparty na całkowitej abstynencji, a którym podejście oparte na redukcji szkód.

Correspondence to/Adres do korespondencji: Robert Modrzyński, Zakład Psychologii Klinicznej i Neuropsychologii, UMCS, pl. Litewski 5, 20-080 Lublin, phone: 4851 2565551, e-mail: modrzynski.robert@gmail.com

Authors' contribution/Wkład pracy autorów: No ghostwriting declared./Nie występuje zjawisko ghostwriting.

Submitted/Otrzymano: 29.11.2017 • Accepted/Przyjęto do druku: 20.02.2018

For the purposes of this article, the author has used study results discussed in his book "Abstinence or moderation of drinking? The significance of resources in the prediction of abstinence of alcohol dependent persons at the early stage of sobriety" published by Difin in 2017. Difin Publishers has allowed the publications of the tables./W artykule autor wykorzystał wyniki badań, które omówił w swojej książce pt. „Abstynencja czy ograniczanie picia? Znaczenie zasobów w przewidywaniu abstynencji osób uzależnionych od alkoholu we wczesnej fazie zdrowienia", opublikowanej przez wydawnictwo Difin w 2017 r. Wydawnictwo Difin wyraziło zgodę na publikację tabel. 
Material and methods: Questionnaire longitudinal studies of 350 alcohol dependent persons were used. A series of 2 comparisons of independent variables (level, gain and loss of resources) were made in the $1^{\text {st }}$ and $6^{\text {th }}$ month following the start of therapy. As measurement method was applied Hobfoll's Conservation of Resources Evaluation Questionnaire (COR-E in Polish version).

Results: Distribution of resources is of great significance in maintaining abstinence. It is important for the alcohol dependent person's recovery process to have the opportunity to gain resources. Personal characteristics resources play a particular role. Experiencing loss of resources at the start of treatment often determines which of the patients will return to drinking.

Discussion: Study analyses provide empirical support for research on the role of supportive factors in alcohol dependent persons recovery process. The project highlights the existence of a group of patients in case of whom harm reduction strategy would be more effective than the total abstinence-based model.

Conclusions: The basic amount of resources and the ability to gain them is the source of motivation for change in the therapy of alcohol dependent persons.

Keywords: Alcohol dependence, Resources, Prediction of abstinence, Conservation of Resources Theory
Materiał i metody: Badania miały charakter podłużny. Zastosowano kwestionariuszowe badania 350 osób uzależnionych od alkoholu. Dokonano serii 2 porównań zmiennej niezależnej (poziom, zysk i strata zasobów) w 1. oraz w 6. miesiącu od rozpoczęcia terapii. Wykorzystano do tego Kwestionariusz Oceny Zachowania Zasobów autorstwa Hobfolla.

Wyniki: Dystrybucja zasobów ma istotne znaczenie w aspekcie utrzymywania abstynencji. Dla procesu zdrowienia osób uzależnionych od alkoholu bardzo ważna jest możliwość zdobywania zasobów. Szczególną rolę odgrywają zasoby podmiotowe. Doświadczanie utraty zasobów na początku leczenia często decyduje o tym, który z pacjentów wróci do picia.

Omówienie: Przeprowadzone analizy stanowią empiryczne wsparcie dla badań nad rolą czynników wspomagających proces zdrowienia osób uzależnionych od alkoholu. Projekt akcentuje fakt istnienia grupy osób uzależnionych od alkoholu, w przypadku których bardziej skuteczna będzie strategia redukcji szkód niż terapia oparta na całkowitej abstynencji.

Wnioski: Źródłem motywacji do zmiany w terapii osób uzależnionych jest posiadanie odpowiedniej ilości zasobów oraz możliwość ich pozyskania.

Słowa kluczowe: uzależnienie od alkoholu, zasoby, przewidywanie abstynencji, Teoria Zachowania Zasobów

\section{- INTRODUCTION}

Conservation of Resources Theory - new

perspectives in dependency therapy

The majority of theories of stress concentrate on cognitive processes and internalisation of stress that limit it to a subjective experience. The dominant concept proposed by Richard Lazarus defines stress as a purely subjective experience as a person's value system, attitudes to life, relations with the environment, opinions, experiences and defined objectives build up the perception of reality [1-3]. The type of coping behaviour a person adopts in crisis situations depends on individual interpretation, and this also includes drinking behaviour.

\section{- Wprowadzenie}

Teoria Zachowania Zasobów - nowe perspektywy dla terapii uzależnień

Większość teorii stresu koncentruje się na procesach poznawczych, uwewnętrznia stres, ograniczając go do subiektywnego przeżycia. Dominująca koncepcja zaproponowana przez Richarda Lazarusa definiuje stres jako przeżycie czysto subiektywne, ponieważ to system wartości człowieka, jego postawy życiowe, relacja $\mathrm{z}$ otoczeniem, poglądy, doświadczenia czy wyznaczone cele budują postrzeganie rzeczywistości [1-3]. Od indywidualnej interpretacji zależy, jakiego typu zachowanie zaradcze podejmie osoba w sytuacjach kryzysowych, w tym również dotyczących picia alkoholu. 
Stevan E. Hobfoll proposes a perspective on the human being in a wider context as an individual rooted in a social structure. Stress and the behaviour resulting from it are not perceived exclusively due to beliefs and resulting behaviour but also because of external and objective conditions that often prevent a person from carrying out life changes that are important for them [4-8].

The basic assumption of Hobfoll's Conservation of Resources Theory (COR) is having and keeping at a specific level that what has been recognised as valuable that is resources: like things, personality traits, conditions and resources of energy. This is the general aim of the majority of human activity. The gain or loss of resources has a fundamental significance to the quality of life and the manner in which people function $[4-6,9,10]$.

The source of motivation is the successful management of one's own resources. Hobfoll unambiguously emphasises that an individual tends to be prone to introducing changes in his or her life only when is in possession of a minimum of resources important for him or her. Dependency is perceived not only as a result of dysfunctional beliefs (with an accompanying therapy focused on disarming the psychological mechanisms of dependency) [11], but also a result of an adverse spiral of experienced gains and losses of resources important for that person.

From the perspective of COR, a reduction of the resources prevents a dependent person from taking up and maintaining themselves in the basic therapy programme and may lead to relapse $[12,13]$. Hobfoll suggests a list of 74 resources important in the gaining of satisfaction with life and divides them into 4 categories $[4,5$, 14] (Figure 1).

Analysis of the list of the most stressful events in a person's life like the death of a spouse, divorce, separation, incarceration or job loss, Hobfoll noted that the common element is a sudden lack of important resources. It is on this basis that the most important rule in his theory is introduced as the factor that most threatens a person's normal functioning is the loss of resources [15-19].

The loss of resources has a massive effect on a person's behaviour but thanks to an increase in the pool of controlled resources, it is possi-
Stevan E. Hobfoll proponuje spojrzenie na człowieka w szerszym kontekście, jako na jednostkę osadzoną w strukturze społecznej. Stres i wynikające $\mathrm{z}$ niego zachowania nie są postrzegane wyłącznie jako wynik przekonań i idących za nimi zachowań, ale również jako rezultat zewnętrznych i obiektywnych warunków, które często uniemożliwiają osobie wprowadzenie ważnych dla niej zmian w życiu [4-8].

Podstawowym założeniem Teorii Zachowania Zasobów (Conservation of Resources - COR) Hobfolla jest posiadanie i utrzymanie na określonym poziomie tego, co zostało uznane za cenne, czyli zasobów: rzeczy, cech osobowości, warunków i pokładów energii. Stanowi to ogólny cel większości działań człowieka. Pozyskiwanie zasobów lub ich utrata ma fundamentalne znaczenie dla jakości życia i sposobu funkcjonowania człowieka $[4-6,9,10]$.

Źródłem motywacji jest pomyślny przebieg procesu zarządzania własnymi zasobami. Hobfoll jednoznacznie podkreśla, że jednostka bywa skłonna do wprowadzania zmian w swoim życiu dopiero wtedy, gdy posiada minimum ważnych dla niej zasobów. Uzależnienie jest spostrzegane nie tylko jako wynik dysfunkcyjnych przekonań (z towarzyszącą terapią skoncentrowaną na rozbrajaniu psychologicznych mechanizmów uzależnienia) [11], lecz także jako rezultat niekorzystnej spirali doświadczanych zysków i strat ważnych dla osoby zasobów.

Z perspektywy COR zmniejszanie się zasobów uniemożliwia osobom uzależnionym podjęcie i utrzymanie się $\mathrm{w}$ podstawowym programie terapii, a także może powodować nawroty picia [12, 13]. Hobfoll proponuje listę 74 zasobów ważnych dla uzyskania satysfakcji z życia i dzieli je na 4 kategorie $[4,5,14]$ (ryc. 1).

Analizując listę najbardziej stresujących wydarzeń w życiu człowieka, takich jak śmierć małżonka, rozwód, separacja, pobyt w więzieniu czy utrata pracy, Hobfoll zauważył, że elementem wspólnym jest nagły brak ważnych zasobów. Na tej podstawie sformułowana została najważniejsza reguła jego teorii mówiąca o tym, że czynnikiem, który najbardziej zagraża prawidłowemu funkcjonowaniu człowieka, jest utrata zasobów [15-19].

Strata zasobów wywiera potężny wpływ na funkcjonowanie człowieka, ale dzięki powiększającej się puli posiadanych zasobów można jej zapobiec lub ją zahamować. Na przykład czas i energia zainwestowane $\mathrm{w}$ rodzinę mogą zapobiec późniejszemu roz- 


\begin{tabular}{|l|}
\hline \multicolumn{1}{|c|}{ OBJECTS } \\
ZASOBY MATERIALNE \\
\hline - physical objects/obiekty \\
fizyczne \\
- an element of \\
socioeconomic status \\
that has a protective \\
function against the \\
harmful effects of \\
stress/element statusu \\
socjoekonomicznego, \\
który pełni funkcję \\
ochronną przed \\
szkodliwym działaniem \\
stresu \\
\end{tabular}

\begin{tabular}{|l|}
\hline \multicolumn{1}{|c|}{ CONDITIONS } \\
ZASOBY STANU
\end{tabular}

Figure 1. Resource categories according to COR Rycina 1. Kategorie zasobów wg COR

ble to avoid or reduce that effect. For example, time and energy invested in the family may prevent a future divorce, and the loss of work is felt less acutely savings have been made earlier. The most effective mechanism for the management of resources is their direct consumption or replacement. When the direct replacement of resources turns out to be impossible, this may take place in a symbolic or indirect manner. This is the compensation of resources [4, 20]. For example, a fall in self-esteem encourages the search for alternative, positive feedback or validation in other areas of life. A failed romance may motivate towards an attempt to raise self-esteem by investing in a professional career and a financial failure may concentrate attention on spiritual development.

The above observations were collected into a set of dependencies allowing relatively accurate prediction of human behaviour. These are presented as follows [4, 21-25]:

"1. Individuals with higher resources will be set up for gains in resources. Similarly, individuals with fewer resources are more likely to experience resource losses.

2. Initial resource loss will lead to resource loss in the future.

3. Initial resource gains will lead to resource gains in the future.

4. A lack of resources will invariably lead to defensive attempts to conserve the remaining resources."

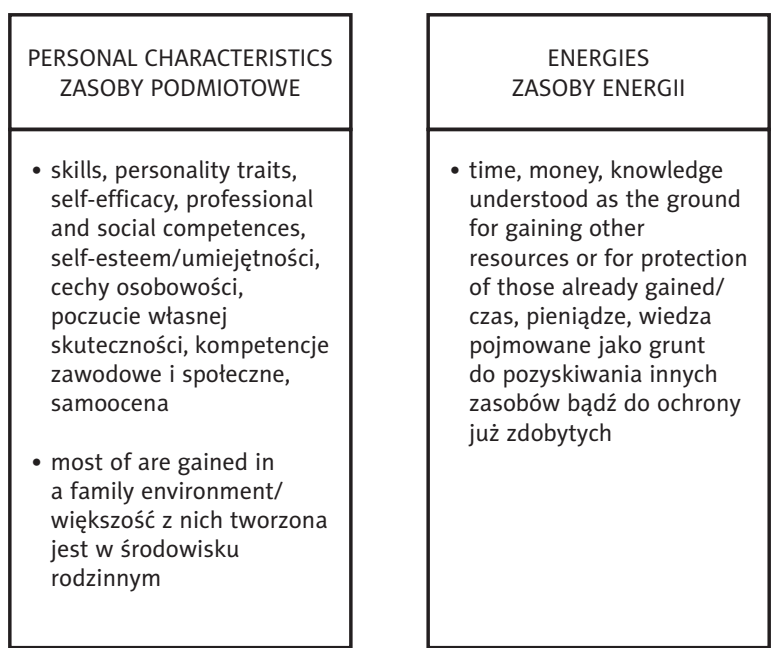

wodowi, a utratę pracy odczuwa się mniej boleśnie, jeśli wcześniej zgromadzone zostały oszczędności. Najbardziej efektywnym mechanizmem zarządzania zasobami jest ich bezpośrednie wydatkowanie lub zastępowanie. Kiedy bezpośrednie zastępowanie zasobów okaże się niemożliwe, może się to odbyć w sposób symboliczny lub pośredni. Mówimy wtedy o kompensowaniu zasobów [4, 20]. Na przykład spadek samooceny skłania do poszukiwania alternatywnych, pozytywnych informacji zwrotnych lub dowartościowania $\mathrm{w}$ innych obszarach życia. Zawód miłosny może motywować do próby podniesienia samooceny przez inwestowanie $\mathrm{w}$ karierę zawodową, a porażka finansowa - do koncentrowania uwagi na rozwoju duchowym.

Powyższe obserwacje zostały zebrane w zbiór zależności pozwalających stosunkowo dokładnie przewidywać zachowanie ludzi. Przedstawiają się one następująco [21-25]:

1. Osoby dysponujące większymi zasobami są mniej narażone na ich utratę i mają większe możliwości osiągania zysku. I odwrotnie, ludzie mający mniej zasobów są bardziej narażeni na ich utratę i mniej zdolni do osiągania zysków.

2. Niedostatek zasobów nie tylko powoduje wzrost ryzyka ich utraty, lecz także sprawia, że strata początkowa pociąga za sobą kolejne.

3. Osoby posiadające zasoby są bardziej zdolne do osiągania kolejnych zysków, a początkowy zysk pociąga za sobą dalsze.

4. Te osoby, którym brakuje zasobów, są skłonne przyjmować postawę defensywną po to, aby strzec tego, co mają. 
Conservation of Resources Theory and dependent persons

Persons of a low level of resources who find themselves in a difficult life situation are frequent among patients in dependency therapy. The disarming of dependency mechanisms among those of, for example, a low level of resources and who return to their environment, may further intensify their stress. Drinking and the dysfunctional beliefs resulting from it helped a dependent person overcome the stress of unemployment, bad socio-existential conditions, a lack of support from the family and friends and loneliness.

Hobfoll suggests that an individual is willing to introduce changes into their lives only when they have a minimum of resources important to them $[5,14]$. In hitherto conducted studies, it is emphasises unambiguously that the experience of a loss of resources affects later failures to achieve therapeutic aims [15].

If a person did not, as a result of drinking, lose important resources, work on the mechanisms of dependency allows an adequate perception of their own situation and acceptance of support as well as gaining satisfaction from contact with the family, friends and work. During active dependency, this was impossible due to dysfunctional beliefs. What leads to change is a beneficial distribution of resources.

It would therefore seem that any polemic around the most effective approach to treating alcohol dependent persons is baseless. Far more important is the complementary character of means of treatment taking into account the answer to the question of which resources a dependent person needs at particular stages of therapy.

The main aim of this article is to examine whether (and in what way), on the basis of resources dynamics, we can predict the maintenance of abstinence by alcohol dependent persons and the relationship between the distribution of resources and their achievement of therapeutic aims. Furthermore, it is equally important to find out to whom it is worth addressing therapy based on the total abstinence model on the one hand and harm-reduction strategy therapy on the other. We formulate our main hypothesis that assumes the maintaining abstinence by dependent persons depends on the distribution of resources.
Teoria Zachowania Zasobów a osoby uzależnione

Wśród pacjentów podejmujących leczenie uzależnienia często spotyka się osoby o niskim poziomie zasobów i znajdujące się w trudnej sytuacji życiowej. Rozbrojenie mechanizmów uzależnienia u osoby np. o niskim poziomie zasobów, która powraca do swojego środowiska, może jeszcze bardziej nasilić jej stres. Picie alkoholu i wynikające $\mathrm{z}$ tego dysfunkcyjne przekonania pomagały jej przetrwać stres związany m.in. $\mathrm{z}$ brakiem zatrudnienia, złymi warunkami socjalno-bytowymi, brakiem wsparcia ze strony rodziny, przyjaciół czy samotnością.

Hobfoll twierdzi, że jednostka jest skłonna do wprowadzania zmian w swoim życiu dopiero wtedy, gdy posiada minimum ważnych dla niej zasobów $[5,14]$. W dotychczasowych badaniach jednoznacznie podkreśla się, że doświadczanie utraty zasobów wpływa na późniejszą porażkę w osiąganiu celów terapeutycznych [15].

Osobie, która w wyniku picia nie utraciła ważnych zasobów, praca nad mechanizmami uzależnienia pozwala na adekwatne spojrzenie na własną sytuację i skorzystanie ze wsparcia, a także na czerpanie zadowolenia $\mathrm{z}$ kontaktów $\mathrm{z}$ rodziną, przyjaciółmi czy z pracy. W okresie czynnego uzależnienia było to niemożliwe $\mathrm{z}$ powodu dysfunkcyjnych przekonań. Tym, co prowadzi do zmiany, jest korzystna dystrybucja zasobów.

Bezzasadny wydaje się więc spór o najbardziej skuteczne podejście w leczeniu osób uzależnionych od alkoholu. O wiele ważniejsza jest komplementarność metod oddziaływania, z uwzględnieniem odpowiedzi na pytanie, jakie zasoby są potrzebne osobie uzależnionej od alkoholu na poszczególnych etapach terapii.

Głównym celem pracy jest uzyskanie odpowiedzi na pytania, czy (i w jaki sposób) na podstawie dynamiki zasobów można przewidywać utrzymywanie abstynencji przez osoby uzależnione od alkoholu oraz jakie zależności istnieją między dystrybucją zasobów a osiąganiem przez te osoby celów terapeutycznych. Ponadto równie ważna jest odpowiedź na pytanie, komu warto zaproponować model terapii oparty na całkowitej abstynencji, a komu - strategię redukcji szkód. Sformułowano główną hipotezę, która zakłada, że utrzymywanie abstynencji przez osoby uzależnione od alkoholu zależy od dystrybucji zasobów. 
This article is based on research project results on the significance of resource distribution for the achievement of therapeutic aims among persons dependent on alcohol at the early stage of returning to health [16].

\section{- Material AND methods}

Questionnaire longitudinal studies were conducted between September 2012 and June 2014. They included 350 patients at 16 alcohol dependency therapy sites. A series of 2 comparisons were conducted of the intensity of independent variables (level of resources, perceived resource loss and perceived resource gain) in the $1^{\text {st }}$ and $6^{\text {th }}$ month following the commencement of therapy.

The results for 350 persons were included in the analysis in the first phase and 155 (90 postal questionnaires and 65 telephone surveys) from the second phase.

Tools serving to measure dependent and independent variables resulted from the accepted theoretical perspective and methodological requirements. The independent variables are level of resources and perceived loss and gain of resources while the dependent variable was maintaining abstinence (dichotomous variable: total abstinence or lack thereof) gained from the catamnestic questionnaire.

The basic tool was S.E. Hobfoll's the Conservation of Resources-Evaluation (COR-E) questionnaire translated into Polish by a team directed by Iwona Niewiadomska at the Chair of Social Psycho-prevention of JPII Catholic University of Lublin. Patients were studied using this questionnaire twice (the $1^{\text {st }}$ and $6^{\text {th }}$ month of therapy).

Additional tool was the catamnestic questionnaire prepared by Robert Modrzyński containing socio-demographic data (metrics) and information on maintaining abstinence and on the course of therapy hitherto undertaken.

The analysis employed a number of statistical methods including the $r$ Pearson correlation coefficient, chi-square test, the $t$-Student test and logistic regression. The IBM statistical package SPSS/ Amos was used for this purpose.

\section{Characteristics of study subjects}

The subject group consisted of 350 persons (71 women and 276 men with a lack of information on gender in 3 cases) of 18-68 years of age with
Niniejszy artykuł powstał na podstawie wyników badań projektu naukowego dotyczącego znaczenia dystrybucji zasobów dla osiągania celów terapeutycznych u osób uzależnionych od alkoholu we wczesnej fazie zdrowienia [16].

\section{- Materiat I metody}

Kwestionariuszowe badania podłużne przeprowadzono w okresie od września 2012 do czerwca 2014 r. Objęto nimi 350 osób leczących się w 16 placówkach terapii uzależnienia od alkoholu. Dokonano serii 2 porównań natężenia zmiennej wyjaśniającej (poziomu zasobów, spostrzeganej utraty zasobów, spostrzeganego wzrostu zasobów) w 1 . oraz 6. miesiącu od rozpoczęcia terapii.

Do analiz włączono wyniki 350 osób z pierwszego badania oraz 155 osób (90 odesłanych kwestionariuszy oraz 65 ankiet wypełnionych telefonicznie) $\mathrm{z}$ drugiego etapu.

Narzędzia służące do pomiaru zmiennych wyjaśnianych (zależnych) i wyjaśniających (niezależnych) wynikały z przyjętej perspektywy teoretycznej oraz wymogów metodologicznych. Zmienne wyjaśniające to poziom zasobów, spostrzegana utrata zasobów i spostrzegany wzrost zasobów, a zmienną wyjaśnianą było utrzymywanie abstynencji (zmienna dychotomiczna: pełna abstynencja lub jej brak) uzyskane $\mathrm{z}$ ankiety katamnestycznej.

Narzędziem podstawowym był Kwestionariusz Oceny Zachowania Zasobów S.E. Hobfolla (COR-E) w polskiej wersji autorstwa zespołu pracowników Katedry Psychoprofilaktyki Społecznej KUL JPII pod kierunkiem Iwony Niewiadomskiej. Pacjentów badano tym kwestionariuszem dwukrotnie (w 1. i w 6. miesiącu od rozpoczęcia terapii).

Dodatkowe narzędzie to ankieta katamnestyczna przygotowana przez Roberta Modrzyńskiego zawierająca dane socjodemograficzne (metryczkę) oraz informacje na temat utrzymywania abstynencji i przebiegu dotychczasowej terapii.

Do analiz wykorzystano kilka metod statystycznych, m.in. współczynnik korelacji $r$ Pearsona, test zgodności $\chi^{2}$, test $t$-Studenta oraz regresję logistyczną. W tym celu użyto pakietu statystycznego IBM SPSS/Amos.

\section{Charakterystyka badanych osób}

Łącznie w badaniu wzięło udział 350 osób, w tym 71 kobiet i 276 mężczyzn (brak informacji o płci dotyczył 3 osób), w wieku 18-68 lat, średnia 
an average age of 42 . There was $9.4 \%$ with basic education, $28.6 \%$ with vocational and $38.9 \%$ with middle and $22.6 \%$ higher.

Most of the subjects were from towns of up to 50,000 residents (35.5\%). Almost every second dependent person taking part in the study (47.7\%) was out of work. Over half of the subjects were married or were in a partnership. The majority had one or two children.

The gained information indicated there was a slight majority of outpatients in the studied population. Most were return patients, especially those who were in therapy for a second time. The second largest group were in treatment for the first time.

The assumption of the second measurement is to predict capacity to maintain abstinence by persons who have undertaken therapy. In order to do so, during the second measurement the subjects were divided into 2 groups according to the fact of abstinence being maintained. During the second study, it was ascertained that 85 persons had observed total abstinence while 70 admitted they had been drinking (one contact with alcohol $3.2 \%$, sporadic drinking $-7.1 \%$ binge drinking $14.2 \%$ and similar style of drinking as before therapy $-19.4 \%)$.

\section{- Results}

The significance of resources in the history of hitherto treatment for maintaining abstinence

The first step of analyses was a comparison of persons who had started treatment (reference t1) as regards later observation of abstinence. The variable differentiating the group of those maintaining abstinence and those who had not is the number of treatments attempted earlier. If alcohol dependent persons had on average two or more treatment episodes in their patient history, then after 6 months they significantly more frequently declared they had broken off abstinence. The difference between the groups is also revealed in the aspect of the amount of taken medications (benzodiazepines) prior to undertaking therapy. Among those who had maintained abstinence, the amount of medication remained at a significantly lower level $(p=0.019)$. Abstinence was also more frequently maintained by persons living with their spouse $(p=0.042)$. wieku 42 lata. Wykształcenie podstawowe miało $9,4 \%$, zawodowe $-28,6 \%$, średnie - $38,9 \%$, a wyższe - 22,6\% osób.

Najliczniejszą grupę stanowiły osoby mieszkające w miejscowościach do 50 tysięcy mieszkańców (35,5\%). Prawie co druga osoba uzależniona biorąca udział w badaniu była bez pracy $(47,7 \%)$. Ponad połowę badanych stanowiły osoby pozostające w związku małżeńskim lub partnerskim. Większość z nich posiadała jedno lub dwoje dzieci.

Uzyskane informacje wskazują na nieznaczną przewagę w badanej populacji osób leczących się ambulatoryjnie. Większość stanowiły osoby mające za sobą wcześniejsze próby leczenia, przede wszystkim takie, które po raz drugi podjęły terapię. Druga co do wielkości grupa to osoby leczące się po raz pierwszy.

Założeniem drugiego pomiaru jest predykcja zdolności do utrzymywania abstynencji przez osoby, które rozpoczęły proces terapii. W tym celu podczas drugiego pomiaru populacja osób badanych została podzielona na 2 grupy ze względu na fakt utrzymywanej abstynencji. Podczas drugiego badania stwierdzono, że pełną abstynencję zachowało 85 osób, natomiast 70 osób przyznało się do picia (jednorazowy kontakt $\mathrm{z}$ alkoholem - 3,2\%, sporadyczne picie - 7,1\%, upijanie się - 14,2\%, podobny styl picia jak przed leczeniem - 19,4\%).

\section{- WYNIKI}

\section{Znaczenie zasobów wynikających $\mathrm{z}$ historii dotychczasowego leczenia dla utrzymywania abstynencji}

Pierwszym krokiem analiz było porównanie osób rozpoczynających leczenie (oznaczenie t1) pod kątem późniejszego utrzymywania abstynencji. Zmienną różnicującą grupę osób, które utrzymały abstynencję, od tych, które jej nie utrzymały, jest liczba podejmowanych wcześniej prób leczenia. Jeśli osoby uzależnione od alkoholu w swojej historii leczenia miały średnio dwie lub więcej odbytych terapii, to po upływie 6 miesięcy istotnie częściej deklarowały złamanie abstynencji. Różnica między grupami zarysowuje się również w aspekcie ilości przyjmowanych leków (benzodiazepin) przed podjęciem terapii. U osób, które zachowały abstynencję, ilość przyjmowanych leków z tej grupy kształtowała się na istotnie niższym poziomie $(p=0,019)$. Abstynencja była również częściej utrzymywana przez osoby mieszkające $\mathrm{z}$ małżonkiem $(p=0,042)$. Kolejnym kryterium 
A further criterion of sustaining abstinence after 6 months was the form of therapy. Among the subjects who had not sustained abstinence, the highest percentage concerned subjects in day-care therapy $(40.6 \%)$. Inpatients $(31 \%)$ or outpatients (46.4\%) were much more likely to sustain abstinence.

Abstinence depends on continuing treatment. In the first 2-3 months of therapy, at the stage of the initial group, the subjects did not indicate differences in sustained abstinence $\left(\chi^{2}(1)=0.221\right.$; $\left.p=0.638 ;{ }_{\text {Kramer's }} \mathrm{V}=0.38\right)$. The population started differentiating only at the treatment continuation stage. Among those who did not take advantage of advanced therapy, as much as $80 \%$ relapsed into drinking.

Subjects who sustained abstinence were more often in individual therapy and psychiatric consultations. Observing abstinence for more than 6 months was declared by $83.5 \%$ of patients that received individual sessions.

Analysis of homogeneity of variance revealed that participating in, on average, 3 forms of therapy to a significant degree decides on maintaining abstinence $(t(153)=-395 ; p<0.001)$. Persons who observed abstinence significantly more often took part in at least 3 forms of therapy. Meanwhile having 2 forms or only 1 significantly predisposes a person to relapse $(p<0.001)$.

Logistic regression allows us to estimate whether independent variable values predict the observance of abstinence. Results indicate the existence of two significant predictors in this aspect: the number of previous attempts at treatment $(\mathrm{t} 1$ measurement in the $1^{\text {st }}$ month of treatment) and the number of continued forms of therapy ( $\mathrm{t} 2$ following the $6^{\text {th }}$ month of treatment). The greater the number of previously undertaken forms of treatment, the lower the probability of maintaining abstinence after 6 months $\left(\chi^{2}(7)=31.897\right.$; $p<0.001 ; R^{2}=0.45$ ).

\section{Predictive function of level of resources in maintaining abstinence}

Persons who were able to sustain abstinence were compared with those who relapsed with respect to their resources. The difference in the level of resources between these persons clearly emerges after 6 months following the start of treatment and concerns each kind of resource (Table I). zdolności utrzymywania abstynencji po 6 miesiącach okazała się forma terapii. Wśród badanych, którzy nie zachowali abstynencji, największy odsetek dotyczy osób uczestniczących w terapii na oddziale dziennym (40,6\%). Pacjenci leczeni stacjonarnie (31\%) lub ambulatoryjnie $(46,4 \%)$ dużo częściej utrzymywali abstynencję.

Abstynencja zależy od kontynuacji podjętego leczenia. W pierwszych 2-3 miesiącach terapii, na etapie tzw. grupy wstępnej, badani nie wykazywali różnic pod kątem utrzymywanej abstynencji $\left(\chi^{2}(1)=0,221 ; p=0,638 ; V_{\text {Kramera }}=0,38\right)$. Populacja zaczynała się różnicować dopiero na etapie kontynuacji leczenia. Spośród osób niekorzystających z form zaawansowanej terapii aż $80 \%$ powróciło do picia.

Badani, którzy utrzymali abstynencję, częściej byli objęci terapią indywidualną oraz konsultacjami psychiatrycznymi. Zachowanie abstynencji po upływie 6 miesięcy deklarowało aż 83,5\% spośród pacjentów uczestniczących w sesjach indywidualnych.

Analiza jednorodności wariancji wykazała, że korzystanie średnio z co najmniej 3 form terapii $\mathrm{w}$ istotnym stopniu decyduje o utrzymaniu abstynencji $(t(153)=-395 ; p<0,001)$. Osoby zachowujące abstynencję istotnie częściej brały udział w co najmniej 3 formach terapii. Natomiast korzystanie już z 2 form terapii lub tylko $\mathrm{z} 1$ istotnie predysponuje osobę do powrotu do picia $(p<0,001)$.

Regresja logistyczna umożliwiła oszacowanie, czy wartości zmiennej niezależnej przewidują utrzymywanie abstynencji. Wyniki wskazują na istnienie dwóch istotnych predyktorów w tym aspekcie: liczby podejmowanych wcześniej prób leczenia ( $\mathrm{t} 1$ - pomiar $\mathrm{w} 1$. miesiącu leczenia) oraz liczby kontynuowanych form terapii ( $\mathrm{t} 2$ - pomiar po 6 miesiącach leczenia). Im większa liczba wcześniejszych prób leczenia, tym mniejsze prawdopodobieństwo utrzymania abstynencji po 6 miesią$\operatorname{cach}\left(\chi^{2}(7)=31,897 ; p<0,001 ; R^{2}=0,45\right)$.

\section{Funkcje predykcyjne poziomu zasobów w utrzymywaniu abstynencji}

Porównano pod kątem poziomu posiadanych zasobów osoby utrzymujące abstynencję z osobami, które powróciły do picia. Różnica w poziomie posiadanych zasobów pomiędzy tymi osobami wyraźnie zarysowuje się po 6 miesiącach od rozpoczęcia leczenia i dotyczy każdego rodzaju zasobów (tab. I). 
Table I. Comparison of people who maintain abstinence and those who relapse due to resource level Tabela I. Porównanie osób utrzymujących abstynencję i powracających do picia pod względem poziomu posiadanych zasobów

\begin{tabular}{|c|c|c|c|c|c|c|c|}
\hline \multirow{3}{*}{ Variables/Zmienne } & \multicolumn{4}{|c|}{ Abstinence(t2)/Abstynencja (t2) } & \multicolumn{3}{|c|}{ Test $t$} \\
\hline & \multicolumn{2}{|c|}{$\begin{array}{l}\text { Maintained } \\
\text { Zachowana }\end{array}$} & \multicolumn{2}{|c|}{$\begin{array}{l}\text { Not maintained } \\
\text { Niezachowana }\end{array}$} & \multirow[b]{2}{*}{$t$} & \multirow[b]{2}{*}{ df } & \multirow[b]{2}{*}{$p$} \\
\hline & M & SD & M & SD & & & \\
\hline $\begin{array}{l}\text { Level of resources (overall result) } \\
\text { Poziom zasobów (wynik ogólny) }\end{array}$ & 175.703 & 39.024 & 135.00 & 38.636 & -4.231 & 84 & 0.000 \\
\hline Objects/Zasoby materialne & 25.656 & 7.458 & 20.727 & 7.808 & -2.643 & 84 & 0.010 \\
\hline $\begin{array}{l}\text { Personal characteristics } \\
\text { Zasoby podmiotowe }\end{array}$ & 55.468 & 12.035 & 44.045 & 12.080 & -3.837 & 84 & 0.000 \\
\hline Energies/Zasoby energii & 37.218 & 10.377 & 29.045 & 8.510 & -3.326 & 84 & 0.001 \\
\hline Conditions/Zasoby stanu & 57.359 & 15.122 & 41.181 & 16.238 & -4.248 & 84 & 0.000 \\
\hline $\begin{array}{l}\text { Differences in the level of all resources } \\
\text { between } \mathrm{t} 2 \text { and } \mathrm{t} 1 \text { (overall result) } \\
\text { Różnice w poziomie wszystkich zasobów } \\
\text { między t2 i t1 (wynik ogólny) }\end{array}$ & 21.072 & 35.456 & -6.062 & 46.187 & -2.511 & 69 & 0.014 \\
\hline $\begin{array}{l}\text { Differences in the level of personal } \\
\text { characteristics (t2-t1) } \\
\text { Różnice w poziomie zasobów } \\
\text { podmiotowych ( } \mathrm{t} 2-\mathrm{t} 1 \text { ) }\end{array}$ & 8.600 & 12.418 & -2.500 & 15.104 & -2.995 & 69 & 0.004 \\
\hline $\begin{array}{l}\text { Differences in the level of energies }(\mathrm{t} 2-\mathrm{t} 1) \\
\text { Różnice } w \text { poziomie zasobów energii }(\mathrm{t} 2 \mathrm{t} \mathrm{t})\end{array}$ & 4.090 & 8.546 & -1.562 & 10.314 & -2.221 & 69 & 0.030 \\
\hline $\begin{array}{l}\text { Differences in the level of conditions (t2-t1) } \\
\text { Różnice w poziomie zasobów stanu (t2-t1) }\end{array}$ & 6.109 & 12.519 & -1.937 & 18.368 & -2.023 & 69 & 0.047 \\
\hline
\end{tabular}

$t 1$ - variable measurement at the moment of starting therapy; 2 - variable measurement after 6 months from the beginning of therapy t1 - pomiar zmiennej w momencie rozpoczynania terapii; $t 2$ - pomiar zmiennej po 6 miesiącach od rozpoczęcia terapii

In order to verify the significance of the level of possessed resources with respect to the likelihood of maintaining abstinence, we constructed a logistic regression model (Table II). In the first stage we introduced into the model variables concerning the history of treatment that came up as significant for the prediction of abstinence i.e. the number of undertaken treatment attempts prior to the first measurement ( $\mathrm{t} 1$ ) and the number of undertaken forms of therapy in the period between the first and second measurement ( $\mathrm{t} 2$ ). In the second stage we introduced variables like the level of resources at the moment of taking up treatment and the difference in the level of resources between the second and first study. The model was statistically significant. The results indicate that the higher the level of resources at the moment of taking up treatment and the greater the difference in the perceived level of resources between the second and first study, the greater the likelihood of maintaining abstinence. So the abstinence of alcohol dependent persons depends on their capacity to dispose of a greater than initial number of resources.
W celu weryfikacji istotności poziomu posiadanych zasobów pod względem prawdopodobieństwa utrzymania abstynencji zbudowano model regresji logistycznej (tab. II). W pierwszym kroku do modelu wprowadzono zmienne dotyczące historii leczenia, które okazały się istotne dla przewidywania abstynencji, tj. liczbę podejmowanych prób leczenia przed pierwszym pomiarem/badaniem (t1) oraz liczbę podejmowanych form terapii w okresie pomiędzy pierwszym a drugim pomiarem/badaniem (t2). W drugim kroku włączono takie zmienne, jak poziom zasobów w momencie podejmowania leczenia oraz różnica $\mathrm{w}$ poziomie zasobów pomiędzy drugim a pierwszym badaniem. Model okazał się istotny statystycznie. Wyniki wskazują, że im wyższy poziom zasobów $\mathrm{w}$ momencie podejmowania leczenia oraz im większa różnica w spostrzeganym poziomie zasobów między drugim a pierwszym badaniem, tym większe prawdopodobieństwo utrzymania abstynencji. Tak więc abstynencja osób uzależnionych od alkoholu zależy od możliwości dysponowania większą niż wyjściowo liczbą zasobów. 
Table II. Logistic regression factor with multiple explanatory variables for the analysis of resource level in the prediction of abstinence in alcohol dependent persons

Tabela II. Wspótczynnik regresji logistycznej z wieloma zmiennymi objaśniającymi dla analizy poziomu zasobów w przewidywaniu utrzymywania abstynencji przez osoby uzależnione od alkoholu

\begin{tabular}{|l|c|c|c|}
\hline Variables/Zmienne & df & $p$ & $\operatorname{Exp}(\mathrm{B})$ \\
\hline Level of resources (overall result)/Poziom zasobów (wynik ogólny) & 1 & 0.030 & 1.024 \\
\hline Level change (overall result)/Zmiana poziomu (wynik ogólny) & 1 & 0.011 & 1.031 \\
\hline
\end{tabular}

$X^{2}(4)=17.063 ; p=0.002 ; R^{2}=0.370$

Next we applied non-parametric regression in which the predicted variable was abstinence while its predictor was the resource level defined in the first study. We used the kernel density estimator in order to plot the density of the variable distribution that is the level of resources. The result, in the form of a regression line (Figure 2) reveals the curvilinear dependence between resources and maintaining abstinence. The probability of maintaining abstinence starts to rise considerably from the raw result of 180 points in Hobfoll's COR test. This allows us to conclude about the existence of a basic trigger level of resources essential to maintain abstinence in the future.

For an in-depth analysis of the level of specific types of resources in the prediction of sustained abstinence by alcohol dependent persons a regression model with multiple independent variables was used. At first significant variables concerning treatment were introduced like the number of previous treatment attempts identified at the first study, the number of undertaken forms of therapy in the period between
Następnie zastosowano regresję nieparametryczną, w której zmienną przewidywaną była abstynencja, a jej predyktorem - poziom zasobów określony podczas pierwszego badania. Zastosowano jądrowy estymator gęstości w celu wyznaczenia gęstości rozkładu zmiennej, jaką jest poziom zasobów. Wynik w postaci linii regresji (ryc. 2) uwidacznia krzywoliniową zależność pomiędzy zasobami a utrzymywaną abstynencją. Od wyniku surowego 180 punktów w teście COR Hobfolla prawdopodobieństwo zachowania abstynencji zaczyna znacznie rosnaćc. Pozwala to wnioskować o istnieniu bazowego „rozruchowego” poziomu posiadanych zasobów niezbędnego do utrzymywania w przyszłości abstynencji.

Do pogłębienia analizy poziomu poszczególnych rodzajów zasobów w predykcji utrzymywania abstynencji przez osoby uzależnione od alkoholu wykorzystano model regresyjny $\mathrm{z}$ wieloma zmiennymi objaśniającymi. Na początku wprowadzono istotne zmienne dotyczące leczenia: liczbę wcześniejszych prób leczenia stwierdzonych podczas pierwszego badania, liczbę odbywanych form terapii w okresie między pierwszym a drugim pomia-

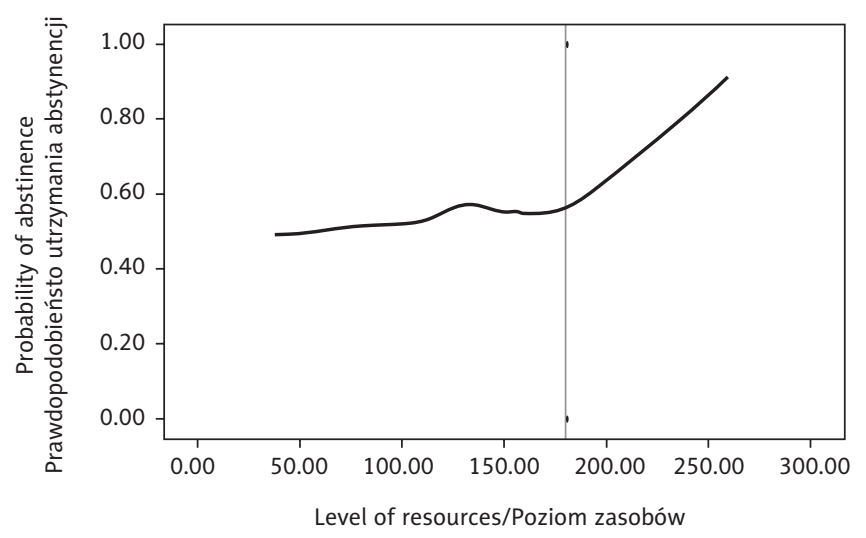

Figure 2. Curvilinear dependence of non-parametric regression on the analysis of resource level in the prediction of abstinence in alcohol dependent people

Rycina 2. Krzywoliniowa zależność regresji nieparametrycznej dla analizy poziomu zasobów w przewidywaniu utrzymania abstynencji u osób uzależnionych od alkoholu 
the first and second study. In the second stage, we introduced the level of resources objects, personal characteristics, energies and conditions from the first study. In the third stage we added the difference in the level of possessed resources between the first and second study. In order to find out which of the specific resources were significant in predicting the observance of abstinence, we conducted a difference test between persons maintaining abstinence and those who did not following the first 6 months of treatment. The meaning of different resource categories in the prediction of maintaining abstinence by persons dependent on alcohol was to be gained using U Mann-Whitney's non-parametric test.

The logistic regression model for level of object resources was statistically significant $\left(\chi^{2}(4)=11.211 ; p=0.024 ; R^{2}=0.255\right)$ and explained approx. $26 \%$ of the variance for alcohol dependent persons' abstinence. A significant variable apart from the number of hitherto undertaken attempts at therapy $(p=0.035 ; \operatorname{Exp}(\mathrm{B})=0.632)$, is the difference in level of possessed resources $(p=0.071$; $\operatorname{Exp}(B)=1.137)$. It is worth however pointing out that this is a relationship at the level of a tendency without statistical significance. If there is a rise in object resources in the period of 6 months following the undertaking of treatment, the probability of maintaining abstinence increases. The level of owned object resources alone at the moment of undertaking therapy does not determine the possibility of maintaining abstinence $(p=0.144)$. It is its increase that supports staying abstinent $(p=0.071)$. The level of these object resources like a place to live appropriate to subject's needs $(p=0.046)$ and the required domestic furnishings $(p=0.031)$ significantly condition the capacity of the person undertaking treatment to later sustain abstinence.

The capacity to maintain abstinence in the first 6 months of therapy depends on initial level of personal characteristic resources $\left(\chi^{2}(4)=18.079 ; p=0.001 ; R^{2}=0.389\right)$, and especially on the sense of realising one's own aims $(p=0.047)$. Also the possibility of a rise in personal characteristic resources in the course of undertaken treatment turns out to be statistically significant $(p=0.005 ; \operatorname{Exp}(B)=1.102)$. This concerns the sense that one is doing well $(p=0.012)$, hope $(p=0.042)$, the sense that one's future success is in one's hands ( $p=0.030)$, not succumbing to a routine $(p=0.022)$, organisational skills $(p=0.029)$, rem. W drugim kroku wprowadzono poziom posiadanych zasobów materialnych, podmiotowych, energii i stanu $\mathrm{z}$ pierwszego pomiaru. $\mathrm{W}$ trzecim kroku dodano różnicę w poziomie posiadanych zasobów między pierwszym a drugim badaniem. Aby odpowiedzieć na pytanie, które z poszczególnych zasobów są istotne $\mathrm{w}$ predykcji utrzymywania abstynencji, przeprowadzono test różnic między osobami utrzymującymi abstynencję a tymi, które jej nie zachowały po 6 pierwszych miesiącach leczenia. Znaczenie różnych kategorii zasobów (materialnych, podmiotowych, energii i stanu) w predykcji zachowywania abstynencji przez osoby uzależnione od alkoholu zostanie uzyskane za pomocą testu nieparametrycznego $U$ Manna-Whitneya.

Model regresji logistycznej dotyczący poziomu zasobów materialnych okazuje się istotny statystycznie $\left(\chi^{2}(4)=11,211 ; p=0,024 ; R^{2}=0,255\right)$; wyjaśnia on ok. $26 \%$ wariancji abstynencji osób uzależnionych od alkoholu. Istotną zmienną, oprócz liczby wcześniej podejmowanych prób terapii $(p=0,035 ; \operatorname{Exp}(B)=0,632)$, jest różnica poziomów posiadanych zasobów $(p=0,071 ; \operatorname{Exp}(\mathrm{B})=1,137)$. Warto jednak zaznaczyć, że jest to związek na poziomie tendencji, bez istotności statystycznej. Jeśli następuje przyrost zasobów materialnych w okresie 6 miesięcy od podjęcia leczenia, to prawdopodobieństwo utrzymania abstynencji wzrasta. Sam poziom posiadanych zasobów materialnych w momencie podejmowania terapii nie determinuje możliwości utrzymania abstynencji $(p=0,144)$. Dopiero jego przyrost sprzyja zachowaniu abstynencji $(p=0,071)$. Poziom takich zasobów materialnych, jak mieszkanie, które odpowiada moim potrzebom $(p=0,046)$, oraz odpowiednie umeblowanie domu ( $p=0,031)$, istotnie warunkuje zdolność osoby podejmującej leczenie do późniejszego utrzymywania abstynencji.

Zdolność do utrzymywania abstynencji $\mathrm{w}$ pierwszych 6 miesiącach terapii zależy od początkowego poziomu posiadanych zasobów podmiotowych $\left(\chi^{2}(4)=18,079 ; p=0,001 ; R^{2}=0,389\right)$; w szczególności od poczucia, że realizuję moje cele $(p=0,047)$. Również możliwość wzrostu zasobów podmiotowych w trakcie podjętego leczenia okazuje się istotna statystycznie $(p=0,005$; $\operatorname{Exp}(\mathrm{B})=1,102)$. Dotyczy to poczucia, że wiedzie mi się $(p=0,012)$, nadziei $(p=0,042)$, poczucia, że moje przyszłe powodzenie zależy ode mnie $(p=0,030)$, niepoddawania się rutynie $(p=0,022)$, umiejętności organizacyjnych $(p=0,029)$, poczucia 
sense of commitment ( $p=0.048$ ), sense of one's own value ( $p=0.041)$, awareness of the purpose to which one moves in life ( $p=0.048)$.

Further analysis revealed that the higher the level of condition resources at the moment of commencing therapy, the higher the chance of maintaining abstinence $\left(\chi^{2}(3)=9.197 ; p=0.027\right.$; $\left.R^{2}=0.213\right)$. The significant predictors are help with childcare $(p=0.049)$, appropriate work status $(p=0.011)$ and stable employment $(p=0.019)$.

Increasing number of energies resources during the treatment positively influences maintaining abstinence $(p=0.031)$. The higher the increase of energy resource level, the higher the probability that the subject will maintain abstinence. The level of significance was reached by resources like strength to realise undertaken projects $(p<0.001)$ and health insurance $(p=0.027)$.

Predictive function of perceived resource gain in maintaining abstinence

The accepted testing strategy for predictive functions for perceived resource gains is analogous to the analysis concerning the importance of the level of owned resources in the prediction of abstinence in alcohol dependent persons.

The first stage of comparison following the $6^{\text {th }}$ month after undertaking therapy by persons maintaining abstinence with those who returned to drinking unambiguously indicates a significant difference between the two in the aspect of sense of gain i.e. improvement in resources. This concerns the general result and the sense of gain in personal characteristic and condition resources. Persons who maintained abstinence declared a significantly greater increase in resources than those who relapsed (Table III).

The next stage of the study covered analysis of the possibility of predicting ability to maintain abstinence on the basis of the results concerning perceived gains. A logistic regression model was created for this purpose to which were introduced the following variables: number of previous treatment attempts, number of undertaken forms of therapy in the period between the first and second measurement, perceived resource gains during the first study and the difference in perceived gains between the second and first measurement.

A vital role in sustaining abstinence in the first months following the start of therapy is played by the gain in personal characteristic resources $(p=0.012 ; \operatorname{Exp}(B)=1.052)$. It is key that a person in zaangażowania ( $p=0,048)$, poczucia własnej wartości $(p=0,041)$, świadomości celu, do jakiego w życiu zmierzam $(p=0,048)$.

Kolejne analizy wykazały, że im wyższy poziom posiadanych zasobów stanu $\mathrm{w}$ momencie rozpoczęcia terapii, tym bardziej wzrasta szansa utrzymania abstynencji $\left(\chi^{2}(3)=9,197 ; p=0,027\right.$; $\left.R^{2}=0,213\right)$. Istotne predyktory to pomoc $\mathrm{w}$ opiece nad dziećmi $(p=0,049)$, odpowiedni status w pracy $(p=0,011)$ oraz stabilna praca $(p=0,019)$.

Powiększająca się liczba zasobów energii $w$ trakcie trwania leczenia wpływa pozytywnie na utrzymanie abstynencji $(p=0,031)$. Im większy wzrost poziomu zasobów energetycznych, tym większe prawdopodobieństwo, że dana osoba zachowa abstynencję. Poziom istotności osiągnęły takie zasoby, jak siła do realizacji podjętych zadań $(p<0,001)$ oraz ubezpieczenie zdrowotne $(p=0,027)$.

\section{Funkcje predykcyjne spostrzeganego zysku zasobów w utrzymywaniu abstynencji}

Przyjęta strategia testowania funkcji predykcyjnych spostrzeganych zysków zasobowych jest analogiczna do analiz dotyczących znaczenia poziomu posiadanych zasobów $\mathrm{w}$ przewidywaniu abstynencji u osób uzależnionych od alkoholu.

W pierwszym etapie porównanie po 6 miesiącach od podjęcia terapii osób utrzymujących abstynencję z tymi, które powrócily do picia, jednoznacznie wskazuje na istotną różnicę pomiędzy nimi $\mathrm{w}$ aspekcie odczuwanego zysku, poprawy w zasobach. Dotyczy to wyniku ogólnego oraz poczucia zysku zasobów podmiotowych i zasobów stanu. Osoby utrzymujące abstynencję deklarowały istotnie większy wzrost zasobów niż osoby, które powróciły do picia (tab. III).

Kolejny etap badań objął analizę możliwości przewidywania zdolności do utrzymywania abstynencji na podstawie wyników dotyczących spostrzeganych zysków. W tym celu został stworzony model regresji logistycznej, do którego wprowadzono następujące zmienne: liczbę podejmowanych wcześniej prób leczenia, liczbę podejmowanych form terapii w okresie pomiędzy pierwszym a drugim pomiarem, spostrzegane zyski zasobowe podczas pierwszego badania i różnicę w spostrzeganych zyskach pomiędzy drugim a pierwszym pomiarem.

Istotną rolę $\mathrm{w}$ utrzymywaniu abstynencji $\mathrm{w}$ okresie pierwszych miesięcy od podjęcia terapii odgrywa pozyskiwanie zasobów podmioto- 
Table III. Comparison of people who maintain abstinence and those who relapse with respect to sense of resource gain Tabela III. Porównanie osób utrzymujących abstynencję i powracających do picia pod względem poczucia zysku posiadanych zasobów

\begin{tabular}{|c|c|c|c|c|c|c|c|}
\hline \multirow{3}{*}{ Variables/Zmienne } & \multicolumn{4}{|c|}{ Abstinence (t2)/Abstynencja (t2) } & \multirow{2}{*}{\multicolumn{3}{|c|}{ Test $t$}} \\
\hline & \multicolumn{2}{|c|}{$\begin{array}{l}\text { Maintained } \\
\text { Zachowana }\end{array}$} & \multicolumn{2}{|c|}{$\begin{array}{l}\text { Not maintained } \\
\text { Niezachowana }\end{array}$} & & & \\
\hline & M & SD & M & SD & $t$ & df & $p$ \\
\hline $\begin{array}{l}\text { Resource gain (overall result) } \\
\text { Zysk zasobów (wynik ogólny) }\end{array}$ & 157.74 & 61.22 & 128.14 & 49.43 & -2.01 & 85 & 0.047 \\
\hline Personal characteristics/Zasoby podmiotowe & 52.87 & 18.15 & 43.71 & 15.30 & -2.08 & 85 & 0.040 \\
\hline Conditions/Zasoby stanu & 52.22 & 21.03 & 40.23 & 18.20 & -2.34 & 85 & 0.021 \\
\hline $\begin{array}{l}\text { Difference in perceived resource gain } \\
\text { between } \mathrm{t} 1 \text { and t2 (overall result) } \\
\text { Różnica w spostrzeganym zysku zasobów } \\
\text { między t1 i t2 (wynik ogólny) }\end{array}$ & 19.90 & 56.13 & -10.80 & 65.36 & -2.08 & 83 & 0.040 \\
\hline $\begin{array}{l}\text { Increase in level of personal characteristics } \\
\text { Wzrost zasobów podmiotowych }\end{array}$ & 9.35 & 19.25 & -1.66 & 20.46 & -2.24 & 83 & 0.028 \\
\hline $\begin{array}{l}\text { Increase in level of conditions } \\
\text { Wzrost zasobów stanu }\end{array}$ & 6.34 & 18.94 & -5.04 & 21.59 & -2.30 & 83 & 0.023 \\
\hline
\end{tabular}

therapy senses a growing improvement in the area of personal characteristic resources during its course. The logistic regression model that considers the perceived increase in personal characteristic resources between the first and second measurement has been shown to be a significant predictor of abstinence in the $6^{\text {th }}$ month following the start of therapy $(p=0.012)$. The greater the perceived increase in personal characteristic resources during the course of treatment, the higher the chance of the dependent person maintaining abstinence. Important personal characteristic resources include the sense of being valuable to others $(p=0.019)$, a sense of realising one's own aims $(p=0.031)$, hope $(p=0.007)$, sense of optimism $(p=0.032)$ and the sense of having one's life under control $(p=0.001)$.

The perception of conditions resources gain takes on a similar significance to personal characteristics resources. The sense of gaining conditions $(p=0.205 ; \operatorname{Exp}(\mathrm{B})=1.022)$ or personal characteristics resources $(p=0.176 ; \operatorname{Exp}(B)=1.027)$ at the start of therapy does not influence the capacity to maintain abstinence. It is only the subjective sense of on improvement in the situation with respect to personal characteristics $(p=176$; Ex$\mathrm{p}(\mathrm{B})=1.027)$ and conditions resources $(p=0.024$; $\operatorname{Exp}(B)=1.042)$ that has been revealed as a significant abstinence predictor.

The conditions resources playing a significant part at the start of therapy include the health of one's own children $(p=0.019)$, health of spouse wych $(p=0,012 ; \operatorname{Exp}(B)=1,052)$. Kluczowe jest, aby osoba poddana terapii odczuwała narastającą, $\mathrm{w}$ miarę jej trwania, poprawę w obszarze zasobów podmiotowych. Model regresji logistycznej, uwzględniający spostrzegany wzrost zasobów podmiotowych pomiędzy pierwszym a drugim pomiarem, okazuje się istotnym predyktorem abstynencji po 6 miesiącach od rozpoczęcia terapii $(p=0,012)$. Im większy spostrzegany wzrost zasobów podmiotowych w trakcie trwania leczenia, tym większe szanse na utrzymanie abstynencji ma osoba uzależniona. Znaczące zasoby podmiotowe to: poczucie, że jestem wartościowy dla innych $(p=0,019)$, poczucie, że realizuję swoje cele $(p=0,031)$, nadzieja $(p=0,007)$, poczucie optymizmu ( $p=0,032)$, poczucie, że mam kontrolę nad swoim życiem $(p=0,001)$.

Spostrzeganie zysku zasobów stanu nabiera podobnego znaczenia jak w przypadku zasobów podmiotowych. Poczucie zysku zasobów stanu $(p=0,205 ; \operatorname{Exp}(\mathrm{B})=1,022)$ czy podmiotowych $(p=0,176 ; \operatorname{Exp}(B)=1,027)$ na początku terapii nie wpływa na zdolność utrzymywania abstynencji. Dopiero subiektywne odczucie poprawiającej się sytuacji $\mathrm{w}$ zakresie zasobów podmiotowych $(p=176 ; \operatorname{Exp}(\mathrm{B})=1,027)$ i stanu $(p=0,024$; $\operatorname{Exp}(B)=1,042)$ okazuje się istotnym predyktorem abstynencji.

Zasoby stanu odgrywające istotną rolę na początku terapii to: zdrowie moich dzieci $(p=0,019)$, zdrowie małżonka/partnera $(p=0,019)$, pomoc 
or partner $(p=0.019)$ and help with childcare ( $p=0.023$ ). During therapy, what is supportive for abstinence is increasing perceived gain in good relations with children $(p=0.037)$, appropriate work status $(p=0.004)$, being part of an organisation that allows one to share one's interests with others $(p=0.009)$, stable employment $(p=0.005)$ and recognition of one's achievements $(p=0.043)$.

Predictive function of perceived loss

of resources in maintaining abstinence

The verification of the perceived resource loss variable in the prediction of abstinence of alcohol dependent persons covered the creation, like in the case of the previous analysis, of a logistic regression model. The first step involved verification of the significance of variables concerning the history of treatment. The second step verified the possibility of predicting abstinence on the basis of intensity of losses in resources in the 12 months prior to undertaking therapy. The third stage additionally considered changes in the intensity of experienced subjective losses in the period between the first and second study (6 months).

A similar comparative strategy for the abstinence maintaining group and the relapsers revealed a significant difference in the scope of perceived loss of resources (Table IV). Subjects that broke abstinence in the 6 months following the start of therapy significantly more often experienced a general loss of resources $(M=80.6$; $\mathrm{SD}=59.3)$, in particular personal characteristics resources $(M=28.9 ; S D=20.2)$.

Logistic regression analysis confirms the dependency by which the smaller the sense of experienced resource loss felt by patients starting therapy, the greater the chances they have of maintaining abstinence. Furthermore, if, in the course of undertaken therapy, the perceived loss of resources is reduced, the likelihood of maintaining abstinence increases (Table V).

Perceived loss of objects resources during the first study is significant in relation to the capacity to predict abstinence. The model taking into account both the loss of resources and the changes in the intensity of losses during therapy unambiguously indicates the role of loss of objects resources on the observation of abstinence $\left(\chi^{2}(4)=10.895\right.$; $\left.p=0.028 ; R^{2}=0.232\right)$. The subjective sense of objects resource loss, in particular those like work tools $(p=0.001)$ and owning more clothes than w opiece nad dziećmi $(p=0,023)$. W trakcie terapii abstynencji sprzyja wzrost postrzeganego zysku w: dobrych relacjach z dziećmi $(p=0,037)$, odpowiednim statusie w pracy $(p=0,004)$, przynależności do organizacji, w której mogę dzielić $\mathrm{z}$ innymi moje zainteresowania $(p=0,009)$, stabilnej pracy $(p=0,005)$ oraz uznaniu dla moich osiągnięć $(p=0,043)$.

\section{Funkcje predykcyjne spostrzeganej utraty \\ zasobów w utrzymywaniu abstynencji}

Weryfikacja zmiennej spostrzeganie strat w zasobach w przewidywaniu abstynencji osób uzależnionych od alkoholu obejmowała utworzenie, analogicznego jak w przypadku poprzednich analiz, modelu regresji logistycznej. Pierwszy krok dotyczył sprawdzenia istotności zmiennych dotyczących historii leczenia. Drugi krok weryfikował możliwość przewidywania abstynencji na podstawie nasilenia strat $\mathrm{w}$ zasobach $\mathrm{w}$ okresie ostatnich 12 miesięcy przed podjęciem terapii. Trzeci etap uwzględnił dodatkowo zmianę nasilenia doświadczanej subiektywnie straty $\mathrm{w}$ okresie pomiędzy pierwszym a drugim badaniem (6 miesięcy).

Analogiczna strategia porównawcza grupy osób utrzymujących abstynencję i powracających do picia wykazała istotne różnice w zakresie doświadczanej utraty zasobów (tab. IV). Osoby, które złamały abstynencję $\mathrm{w}$ okresie 6 miesięcy od rozpoczęcia terapii, istotnie częściej doświadczały ogólnej utraty zasobów $(M=80,6$; $\mathrm{SD}=59,3)$, w szczególności zasobów podmiotowych $(\mathrm{M}=28,9 ; \mathrm{SD}=20,2)$.

Analiza regresji logistycznej potwierdza zależność, że im mniejsze poczucie doświadczanej utraty zasobów ma pacjent rozpoczynający leczenie, tym większą ma szansę na utrzymanie abstynencji. Ponadto, jeżeli w trakcie podjętej terapii spostrzegana utrata zasobów ulega zmniejszeniu, to zwiększa się prawdopodobieństwo utrzymania abstynencji (tab. V).

Spostrzeganie utraty zasobów materialnych podczas pierwszego badania jest istotne w odniesieniu do zdolności przewidywania abstynencji. Model uwzględniający zarówno utratę zasobów, jak i zmianę nasilenia strat $\mathrm{w}$ trakcie terapii jednoznacznie wskazuje na rolę w utrzymywaniu abstynencji, jaką pełni utrata zasobów materialnych $\left(\chi^{2}(4)=10,895 ; p=0,028 ; R^{2}=0,232\right)$. Subiektywnie odczuwana utrata zasobów materialnych, w szczególności takich, jak narzędzia potrzebne 
Table IV. Comparison of persons who maintain abstinence and those who relapse due to sense of resource loss Tabela IV. Porównanie osób utrzymujących abstynencję i powracających do picia pod względem poczucia utraty zasobów

\begin{tabular}{|c|c|c|c|c|c|c|c|}
\hline \multirow{3}{*}{ Variables/Zmienne } & \multicolumn{4}{|c|}{ Abstinence (t2)/Abstynencja (t2) } & \multirow{2}{*}{\multicolumn{3}{|c|}{ Test $t$}} \\
\hline & \multicolumn{2}{|c|}{$\begin{array}{l}\text { Maintained } \\
\text { Zachowana }\end{array}$} & \multicolumn{2}{|c|}{$\begin{array}{l}\text { Not maintained } \\
\text { Niezachowana }\end{array}$} & & & \\
\hline & M & SD & $M$ & SD & $t$ & df & $p$ \\
\hline $\begin{array}{l}\text { Sense of resource loss (overall result) } \\
\text { Poczucie utraty zasobów (wynik ogólny) }\end{array}$ & 43.68 & 57.35 & 80.61 & 59.31 & 2.539 & 83 & 0.013 \\
\hline $\begin{array}{l}\text { Perceived loss of personal characteristics } \\
\text { Spostrzegana utrata zasobów podmiotowych }\end{array}$ & 12.31 & 18.37 & 28.90 & 20.23 & 3.502 & 83 & 0.001 \\
\hline $\begin{array}{l}\text { Reduction in the perceived loss of personal } \\
\text { characteristics (t1-t2) } \\
\text { Zmniejszenie spostrzeganej utraty zasobów } \\
\text { podmiotowych (t1-t2) }\end{array}$ & -28.80 & 26.33 & -12.47 & 21.11 & 2.467 & 79 & 0.016 \\
\hline
\end{tabular}

Table V. Logistic regression factor with multiple explanatory variables for the sense of resources loss in the prediction of maintaining abstinence in alcohol dependent persons

Tabela V. Współczynnik regresji logistycznej z wieloma zmiennymi objaśniającymi dla poczucia utraty zasobów w przewidywaniu utrzymywania abstynencji przez osoby uzależnione od alkoholu

\begin{tabular}{|c|c|c|c|}
\hline Variables/Zmienne & df & $p$ & $\operatorname{Exp}(B)$ \\
\hline Number of previous treatment attempts/Liczba wcześniejszych prób terapii & 1 & 0.017 & 0.584 \\
\hline Sense of resource loss (overall result)/Poczucie straty w zasobach (wynik ogólny) & 1 & 0.026 & 0.984 \\
\hline $\begin{array}{l}\text { Reduction in the perceived resources loss t1-t2 (overall result) } \\
\text { Zmniejszenie spostrzeganej utraty zasobów t1-t2 (wynik ogólny) }\end{array}$ & 1 & 0.005 & 0.982 \\
\hline
\end{tabular}

$X^{2}(4)=14.334 ; p=0.006 ; R^{2}=0.294$

one needs $(p=0.60)$, determines later maintenance of abstinence.

In the case of a loss of personal characteristics resources $\left(\chi^{2}(4)=18.620 ; p=0.001 ; R^{2}=0.370\right)$ and energies resources $\left(\chi^{2}(4)=11.505 ; p=0.021\right.$; $\left.R^{2}=0.241\right)$ we observe similar dependencies like in the case of experiencing object resource losses. Both the sense of a loss of personal characteristics and energies resources has a determining influence on the effect of therapy in a patient undertaking dependency treatment. Persons who declare reduced intensity of energy losses have a greater chance of maintaining abstinence as regards time for work $(p=0.016)$, health insurance $(p=0.044)$ and personal characteristics resources like a sense of one's worth to others $(p=0.004)$, a sense of realising one's purpose ( $p=0.031)$, hope $(p=0.013)$, not falling into a routine $(p=0.010)$, organisational skills $(p=0.033)$, positive feelings as regards oneself ( $p=0.009)$, a sense that one is doing well $(p=0.027)$ and a sense of pride in oneself $(p=0.051)$.

Maintaining abstinence depends also on reduced perception of conditions resources do pracy $(p=0,001)$ i posiadanie większej ilości ubrań niż się potrzebuje $(p=0,60)$, determinuje późniejsze utrzymywanie abstynencji.

W przypadku utraty zasobów podmiotowych $\left(\chi^{2}(4)=18,620 ; p=0,001 ; R^{2}=0,370\right)$ i zasobów energii $\left(\chi^{2}(4)=11,505 ; p=0,021 ; R^{2}=0,241\right)$ obserwujemy podobne zależności jak w przypadku doświadczania utraty w zasobach materialnych. Zarówno poczucie utraty zasobów podmiotowych, jak i energetycznych ma determinujący wpływ na efekty terapii u pacjenta podejmującego leczenie uzależnienia. Większe szanse na utrzymanie abstynencji mają osoby deklarujące zmniejszające się nasilenie utraty zasobów energii: czas na pracę $(p=0,016)$, ubezpieczenie zdrowotne ( $p=0,044)$, oraz zasobów podmiotowych: poczucie, że jestem wartościowy dla innych $(p=0,004)$, poczucie, że realizuję moje cele $(p=0,031)$, nadzieja $(p=0,013)$, niepoddawanie się rutynie $(p=0,010)$, umiejętności organizacyjne $(p=0,033)$, pozytywne uczucie względem siebie $(p=0,009)$, poczucie, że wiedzie mi się $(p=0,027)$ oraz poczucie dumy z siebie $(p=0.051)$.

Utrzymywanie abstynencji zależy również od zmniejszającej się w trakcie terapii spostrzeganej 
loss during therapy $\left(\chi^{2}(4)=11.394 ; p=0.022\right.$; $\left.R^{2}=0.239\right)$. This, in particular concerns resources like recognition of achievement $(p=0.007)$ and vital energy/resilience $(p=0.011)$.

Significance of resource dynamics in prediction the possibility of applying the harm-reduction approach in alcohol dependence therapy

We constructed a range of logistic regression models with the purpose of verifying hypotheses concerning the significance of resources in the prediction of relapse in the subjects: a relapse into drinking in a similar or worse style than prior to undertaking therapy. We applied the backward elimination method, which involved first introducing all the analysed predictors and then with each next step remove successive insignificant variables. It is in this way that we identified significant alcohol relapse predictors.

Analyses of resources resulting from the catamnestic questionnaire indicated predictors that pointed out a group of dependent persons who do not maintain abstinence and return to the previous style of drinking. We isolated factors like previous experience of homelessness $\left(\chi^{2}(1)=3.331\right.$; $p=0.068)$, not living with a spouse $\left(\chi^{2}(1)=4.201\right.$; $p=0.040)$, lack of children $\left(\chi^{2}(1)=8.720\right.$; $p=0.003)$, previous incarceration $\left(\chi^{2}(1)=12.462\right.$; $p<0.001)$ and experience of mental disorders $\left(\chi^{2}(1)=3.927 ; p=0.048\right)$.

The categorisation of variable that is the number of previously undertaken attempts at treatment revealed significant links to a failure to maintain abstinence $\left(\chi^{2}(2)=14.073 ; p=0.001\right)$. Dependent persons who undertook three or more previous attempts at treatment significantly more often declared a return to drinking similar or more destructive that prior to the initiation of therapy (39.1\%). Analogical analysis was conducted taking into account the number of detoxifications undertaken previously. It was revealed that two detoxifications or more prior to undertaking therapy predisposes a person to be classified in the group that applies the harm-reduction approach $\left(\chi^{2}(2)=7.296 ; p=0.026\right)$.

The level of available resources at the time of undertaking treatment has a significant role in the prediction of destructive drinking-style relapse. The lower the level of condition resources declared by the subject at the moment of commencing therapy, the greater the probability that utraty zasobów stanu $\left(\chi^{2}(4)=11,394 ; p=0,022\right.$; $\left.R^{2}=0,239\right)$. Dotyczy to w szczególności takich zasobów, jak uznanie dla osiągnięć $(p=0,007)$ i siły witalne/wytrzymałość ( $p=0,011)$.

\section{Znaczenie dynamiki zasobów \\ w przewidywaniu możliwości stosowania strategii redukcji szkód w terapii uzależnienia od alkoholu}

Zbudowano szereg modeli regresji logistycznej w celu weryfikacji hipotez dotyczących znaczenia zasobów w przewidywaniu nawrotów picia u badanych - picia w podobnym lub gorszym stylu niż przed podjęciem terapii. Zastosowano metodę selekcji wstecznej polegającą na wprowadzeniu początkowo wszystkich analizowanych predyktorów, by następnie $\mathrm{z}$ każdym krokiem usuwać kolejne nieistotne zmienne. W ten sposób wyodrębniono istotne predyktory nawrotów picia.

Analizy dotyczące zasobów wynikających z ankiety katamnestycznej wskazały na predyktory wyłaniające grupę osób uzależnionych, które nie utrzymają abstynencji i powrócą do poprzedniego stylu picia. Wyodrębniono takie czynniki, jak: doświadczanie w przeszłości bezdomności $\left(\chi^{2}(1)=3,331 ; p=0,068\right)$, niezamieszkiwanie $\mathrm{z}$ małżonkiem $\left(\chi^{2}(1)=4,201 ; p=0,040\right)$, brak dzieci $\left(\chi^{2}(1)=8,720 ; p=0,003\right)$, wcześniejszy pobyt w zakładzie karnym $\left(\chi^{2}(1)=12,462 ; p<0,001\right)$ oraz doświadczanie zaburzeń psychicznych $\left(\chi^{2}(1)=3,927 ; p=0,048\right)$.

Kategoryzacja zmiennej, jaką jest liczba wcześniej podejmowanych prób leczenia, ujawniła istotne związki z brakiem utrzymywania abstynencji $\left(\chi^{2}(2)=14,073 ; p=0,001\right)$. Osoby uzależnione, które podejmowały trzy lub więcej wcześniejszych prób leczenia, istotnie częściej deklarowały powrót do picia podobnego lub bardziej destrukcyjnego niż przed rozpoczęciem terapii $(39,1 \%)$. Analogicznych analiz dokonano, uwzględniając liczbę podejmowanych wcześniej detoksykacji. Okazuje się, że dwie detoksykacje lub więcej przed podjęciem terapii predysponują osobę do zaklasyfikowania jej do grupy, w której stosuje się strategię redukcji szkód $\left(\chi^{2}(2)=7,296 ; p=0,026\right)$.

Poziom posiadanych zasobów $w$ chwili podejmowania leczenia ma istotne znaczenie w przewidywaniu powrotu do destrukcyjnego stylu picia. Im niższy poziom posiadanych zasobów stanu deklaruje osoba w chwili podejmowania terapii, tym większe prawdopodobieństwo, 
they will return to drinking with a similar intensity as prior to starting treatment $\left(\chi^{2}(7)=41.845\right.$; $\left.p<0.001 ; R^{2}=0.641\right)$.

The most important resources in the prediction of applying the harm-reduction approach are a successful marriage $(p=0.034)$, a stable family $(p=0.033)$, a sense of being close to a spouse or partner $(p=0.044)$, financial security in retirement ( $p=0.007)$ and the sense that one is realising one's purpose $(p=0.007)$.

Analysis of sense of gaining resources indicated the significant relevance of the situation of gaining object and personal characteristics resources $\left(\chi^{2}(7)=51.070 ; p<0.001 ; R^{2}=0.652\right)$. Perceived improvement in material situation in the period preceding therapy indicates, with a large probability, that a subject does not maintain abstinence and relapses $(B=0.153)$. The opposite situation concerns personal characteristic resources, the increase of which causes a reduction in the probability of relapse to a similar drinking style $(\mathrm{B}=-0.61)$.

In the prediction of the application of the harmreduction approach, special attention ought to be drawn to condition resources. A lack of membership of an organisation in which one may share one's interests with others $(p=0.026)$ and a deficit in having at least one friend $(p=0.045)$ felt in the first months of recovery is one of the main factors contributing to relapse.

Testing of the predictive function of perceived resource loss revealed significant relevance of experiencing this loss in the case of relapse $\left(\chi^{2}(7)=49.304 ; p<0.001 ; R^{2}=0.643\right)$. The specific resources which perceived loss significantly differentiate the studied population as regards capacity to maintain abstinence were identified. The most important include more clothes than one needs $(p=0.032)$, tools needed for work $(p=0.004)$, accommodation meeting one's needs $(p=0.036)$, suitable domestic furnishings $(p=0.044)$, a sense that one's life is under control $(p=0.027)$, a sense that one's life is calm $(p=0.022)$, self-discipline ( $p=0.026)$, a sense that one's life has a purpose $(p=0.016)$, development through education or professional training $(p=0.020)$, time for work $(p=0.035)$, savings for a rainy day $(p=0.002)$, financial stability $(p=0.018)$, health insurance $(p=0.019)$, money for personal development, self-improvement $(p=0.019)$, financial support when required $(p=0.026)$, the health of family że powróci do picia o podobnej intensywności jak przed rozpoczęciem leczenia $\left(\chi^{2}(7)=41,845\right.$; $\left.p<0,001 ; R^{2}=0,641\right)$.

Najbardziej kluczowe zasoby w predykcji stosowania strategii redukcji szkód to: udane małżeństwo $(p=0,034)$, stabilność rodzinna $(p=0,033)$, poczucie bliskości z małżonkiem lub partnerem $(p=0,044)$, zabezpieczenie finansowe $\mathrm{w}$ okresie emerytury $(p=0,007)$ oraz poczucie, że realizuje moje cele $(p=0,007)$.

Analiza poczucia zysku zasobów wskazała na istotne znaczenie sytuacji pozyskiwania zasobów materialnych i podmiotowych $\left(\chi^{2}(7)=51,070\right.$; $\left.p<0,001 ; R^{2}=0,652\right)$. Spostrzeganie poprawy sytuacji materialnej w okresie poprzedzającym terapię $\mathrm{z}$ dużym prawdopodobieństwem wskazuje na to, że osoba nie utrzyma abstynencji i powróci do picia $(B=0,153)$. Odwrotna sytuacja dotyczy zasobów podmiotowych, których wzrost powoduje zmniejszenie prawdopodobieństwa powrotu do podobnego stylu picia $(\mathrm{B}=-0,61)$.

W predykcji stosowania strategii redukcji szkód szczególną uwagę należy zwrócić na zasoby stanu. Brak przynależności do organizacji, w której mogę dzielić z innymi moje zainteresowania $(p=0,026)$, oraz deficyt $\mathrm{w}$ posiadaniu przynajmniej jednego przyjaciela $(p=0,045)$ odczuwany w pierwszych miesiącach zdrowienia jest jednym $\mathrm{z}$ głównych czynników powodujących nawrót picia.

Testowanie funkcji predykcyjnych spostrzegania utraty zasobów ujawnia istotne znaczenie doświadczania tej utraty w przypadku nawrotów picia $\left(\chi^{2}(7)=49,304 ; p<0,001 ; R^{2}=0,643\right)$. Wyłonione zostały te konkretne zasoby, spostrzeganie utraty których istotnie różnicuje badaną populację ze względu na zdolność do utrzymywania abstynencji. Do najbardziej kluczowych należą: więcej ubrań niż potrzebuję $(p=0,032)$, narzędzia potrzebne do pracy $(p=0,004)$, mieszkanie, które odpowiada moim potrzebom $(p=0,036)$, odpowiednie umeblowanie domu ( $p=0,044)$, poczucie, że mam kontrolę nad swoim życiem ( $p=0,027)$, poczucie, że moje życie jest spokojne $(p=0,022)$, samodyscyplina $(p=0,026)$, poczucie, że moje życie ma sens $(p=0,016)$, rozwijanie się przez edukację lub doskonalenie zawodowe $(p=0,020)$, czas na pracę $(p=0,035)$, oszczędności na nieprzewidziane wydarzenia $(p=0,002)$, stabilność finansowa $(p=0,018)$, ubezpieczenie zdrowotne $(p=0,019)$, pieniądze na rozwój osobisty, samodoskonalenie $(p=0,019)$, pomoc finansowa, gdy zachodzi potrzeba $(p=0,026)$, 
and close friends $(p=0.050)$, appropriate financial security $(p=0.007)$, appropriate work status $(p=0.019)$, co-workers' support $(p=0.001)$, people one can learn from $(p<0.001)$, support in realising work projects $(p=0.005)$, involvement in a church or religious community $(p=0.043)$ and loyal friends $(p=0.044)$.

\section{- Discussion}

The study results have allowed us to pinpoint the factors playing a predictive role in the capacity to maintain abstinence. The specific resources that regulate whether a patient will have a greater or smaller chance of maintaining abstinence were identified.

Relevant factors linked to resources in the initial phase of treatment

1. A patient's capacity to maintain abstinence during treatment is dependent on the level of personal characteristic and condition resources available at the moment of starting treatment.

Level of resources like a sense of realising one's own purpose, development through education or professional training, a sense of control over one's own life, a sense of self pride, recognition of achievements, support with childcare and children's health decide on the success of maintaining abstinence.

It was found that the variable differentiating the study group in the aspect of maintaining abstinence was living with a spouse or partner and living together with children.

2. Socio-demographic factors and those concerning the history of treatment allowing the prediction of later relapse are two previous undertaken therapies or more, two detoxifications or more, the experience of being homeless, not living with a spouse or partner, childlessness, incarceration and mental disorders comorbid with dependency.

3. The lower the level of personal characteristic, condition, object and energy resources declared by a subject at the time of undertaking therapy, the greater the probability of relapse to the earlier drinking style.

This concerns the level of resources like securing the essentials for children, aids for children's additional requirements, appropriate financial security, financial stability, financial security during retirement, a sense of per- zdrowie rodziny, bliskich przyjaciół $(p=0,050)$, odpowiednie zabezpieczenie finansowe $(p=0,007)$, odpowiedni status w pracy $(p=0,019)$, wsparcie od współpracowników $(p=0,001)$, ludzie, od których mogę się uczyć $(p<0,001)$, pomoc w realizowaniu zadań w pracy $(p=0,005)$, zaangażowanie w kościelnej wspólnocie religijnej $(p=0,043)$ oraz lojalność przyjaciół $(p=0,044)$.

\section{- OmóWIEnIE}

Wyniki badań pozwoliły wytypować czynniki pełniące funkcję predykcyjną co do zdolności utrzymania abstynencji. Wyłonione zostały poszczególne zasoby, od których zależy, czy pacjent będzie miał większe bądź mniejsze szanse na utrzymanie abstynencji.

Czynniki związane z zasobami ważne na etapie rozpoczynania leczenia

1. Od poziomu zasobów podmiotowych i stanu, jakie posiada pacjent w momencie rozpoczęcia terapii, jest uzależniona jego zdolność do utrzymania abstynencji w trakcie leczenia.

Poziom zasobów - takich jak poczucie realizowania własnych celów, rozwijanie się przez edukację lub doskonalenie zawodowe, poczucie kontroli nad własnym życiem, poczucie dumy z siebie, uznanie osiągnięć, pomoc w opiece nad dziećmi, zdrowie dzieci - decyduje o sukcesie w utrzymaniu abstynencji.

Okazało się, że zmienną różnicującą badaną grupę w aspekcie utrzymywania abstynencji jest mieszkanie $\mathrm{z}$ małżonkiem/konkubentem oraz wspólne mieszkanie z dziećmi.

2. Czynniki socjodemograficzne i czynniki dotyczące historii leczenia pozwalające przewidywać późniejszy nawrót picia to: dwie lub więcej wcześniej odbyte terapie, dwie lub więcej detoksykacje, doświadczenie bezdomności, niezamieszkiwanie z małżonkiem/partnerem, bezdzietność, pobyt w zakładzie karnym oraz współistniejące z uzależnieniem zaburzenia psychiczne.

3. Im niższy poziom zasobów podmiotowych, stanu, materialnych i zasobów energii deklaruje dana osoba $\mathrm{w}$ chwili podejmowania terapii, tym większe jest prawdopodobieństwo jej powrotu do wcześniejszego stylu picia.

Dotyczy to poziomu takich zasobów, jak zabezpieczenie niezbędnych środków dzieciom, środków na dodatkowe potrzeby dzieci, odpowiednie zabezpieczenie finansowe, stabilność finansowa, zabezpieczenie finansowe $\mathrm{w}$ okresie emerytury, 
sonal pride, a sense of realising one's purpose, self-discipline, positive self-regard, a successful marriage, stable family, a sense of closeness with spouse or partner, good relations with children and healthy children.

4. Object resources are a significant determining factor in relapse. The experience of an improvement or sudden deterioration in material situation at the moment of undertaking treatment indicates a large probability of failing to maintain abstinence in the future.

Relevant factors linked to resources important during the course of treatment

5. Study results show that the possibility of an increase of resources in the course of therapy supports the maintaining of abstinence. What is key is a rise in the level of available personal characteristic resources like a sense of success, hope, influence on the future, not falling into a routine, organisational skills, a sense of involvement, a sense of one's own value, an awareness of purpose in life, and awareness that life makes sense, a sense of independence, peace and a sense of realising one's own goals.

No less significant in the maintaining of abstinence is the gain of objects resources (accommodation adequate to needs, essential domestic furnishing), conditions resources (vital strength/ resilience, stable work, appropriate work status and involvement in a church or religious community) or energies resources (strength to realise undertaken projects and health insurance).

6. The sense of an increase in resources is a positive factor influencing the maintaining of abstinence by alcohol-dependent persons. Of specific significance in this context is a noticeable improvement in personal characteristics resources (a sense of being valued, a sense of realising one's own purposes, hope, optimism, a sense of having control over one's own life, self-discipline, self-pride and a sense of one's own value) and conditions resources (good relations with children, a stable job, appropriate professional status, support in realising work projects, understanding on the part of the employer, recognition of achievement, company and membership of an organisation). Not only a real rise in available resources but also an emotionally sensed improvement in this aspect increases the chances of maintaining abstinence in the course of therapy. poczucie dumy z siebie, poczucie, że realizuje się własne cele, samodyscyplina, pozytywne uczucia względem siebie, udane małżeństwo, stabilność rodzinna, poczucie bliskości z małżonkiem lub partnerem, dobre relacje $\mathrm{z}$ dziećmi, zdrowie dzieci.

4. Zasoby materialne to istotny czynnik determinujący nawrót picia. Doświadczenie poprawy lub nagłego pogorszenia sytuacji materialnej $\mathrm{w}$ momencie podejmowania leczenia wskazuje na duże prawdopodobieństwo nieutrzymania w przyszłości abstynencji.

\section{Czynniki związane z zasobami ważne na} etapie już podjętego leczenia

5. Wyniki badania wskazują, że możliwość wzrostu zasobów w trakcie trwania terapii sprzyja utrzymaniu abstynencji. Kluczowy okazuje się wzrost poziomu posiadanych zasobów podmiotowych, takich jak poczucie powodzenia, nadzieja, wpływ na przyszłość, niepoddawanie się rutynie, umiejętności organizacyjne, poczucie zaangażowania, poczucie własnej wartości, świadomość celu w życiu, poczucie sensu życia, poczucie niezależności, spokoju oraz poczucie realizowania własnych celów.

Nie mniej istotne w utrzymaniu abstynencji jest pozyskiwanie zasobów materialnych (mieszkanie odpowiadające potrzebom, niezbędne wyposażenie domu), zasobów stanu (siły witalne/ wytrzymałość, stabilna praca, odpowiedni status w pracy, zaangażowanie w sprawy kościoła lub we wspólnotę religijną) czy zasobów energii (siła do realizacji podjętych zadań, ubezpieczenie zdrowotne).

6. Poczucie wzrostu zasobów jest czynnikiem pozytywnie wpływającym na utrzymywanie abstynencji przez osoby uzależnione od alkoholu. Szczególne znaczenie ma w tym kontekście odczuwana poprawa w zasobach podmiotowych (poczucie bycia wartościowym, poczucie realizowania własnych celów, nadzieja, optymizm, poczucie kontrolowania własnego życia, samodyscyplina, duma $\mathrm{z}$ siebie, poczucie własnej wartości) oraz $\mathrm{w}$ zasobach stanu (dobre relacje z dziećmi, stabilna praca, odpowiedni status zawodowy, pomoc w realizowaniu zadań w pracy, zrozumienie ze strony pracodawcy, uznanie dla osiągnięć, towarzystwo, przynależność do organizacji). Nie tylko realny wzrost posiadanych zasobów, ale i emocjonalne odczuwanie poprawy $\mathrm{w}$ tym aspekcie zwiększa szansę na utrzymanie abstynencji w trakcie trwającej terapii. 
7. The experience of resource loss during the course of therapy has a decisive influence as regards maintaining abstinence. The sheer number of resources in every category the loss of which increases the probability of a relapse emphasises unambiguously how fragile and sensitive the period of the first 6 months of treatment is.

Subjects who at a later time declared they had broken off abstinence significantly more often experienced the loss of the resources mentioned below. This includes object resources (more clothes than needed, tools needed for work, accommodation that meets requirements and appropriate furnishings), personal characteristics resources (a sense of control over one's own life, a sense that life is calm, self-discipline, a sense of the purpose of life, personal development by education or professional training), energy resources (time for work, savings or money put aside for a rainy day, financial stability, health insurance, money for personal development, financial support if required, the health of family and friends and appropriate financial security) and condition resources (support from co-workers, people one can learn from, help in realising work projects, involvement in a church or religious community and the loyalty of friends).

The gained results on the one hand confirm the relevance of Hobfoll's COR theory while on the other empirically support current analysis on the basis of Polish studies and enrich them with specific tools for therapeutic work [26-36]. The analyses above at the same time constitute an empirical support for research into the role of factors that promote the process of alcohol dependent persons' return to health $[15,16$, 37-39].

Analysis of the results accentuates the fact of the existence of a group of alcohol dependent persons who do not take advantage of therapy based on total abstinence and will not achieve a therapeutic aim formulated as such [38-40]. Taking into account the cost and indicator of this type of treatment's effectiveness, it becomes justified to seek criteria supporting the classification of patients to a standard programme of treatment or to an alternative form of help that is the harm-reduction approach. The thesis is also in line with current postulates contributed by authors advocating the harm-reduction approach [41-44].
7. Doświadczenie utraty zasobów w trakcie trwania terapii ma decydujące znaczenie w kwestii dotyczącej utrzymywania abstynencji. Mnogość zasobów z każdej kategorii, których utrata zwiększa prawdopodobieństwo powrotu do picia, podkreśla jednoznacznie, jak kruchym i wrażliwym okresem jest pierwszych 6 miesięcy zdrowienia.

Utraty niżej wymienionych zasobów znacznie częściej doświadczały osoby, które w późniejszym okresie deklarowały złamanie abstynencji. Dotyczy to zasobów materialnych (więcej ubrań niż potrzebuję, narzędzia potrzebne do pracy, mieszkanie, które odpowiada moim potrzebom, odpowiednie umeblowanie domu), zasobów podmiotowych (poczucie, że mam kontrolę nad własnym życiem, poczucie, że moje życie jest spokojne, samodyscyplina, poczucie, że moje życie ma sens/cel, rozwijanie się przez edukację lub doskonalenie zawodowe), zasobów energii (czas na pracę, oszczędności lub pieniądze na nieprzewidziane wydarzenia, stabilność finansowa, ubezpieczenie zdrowotne, pieniądze na rozwój osobisty, samodoskonalenie, pomoc finansowa, gdy zachodzi potrzeba, zdrowie rodziny i przyjaciół, odpowiednie zabezpieczenie finansowe), zasobów stanu (wsparcie ze strony współpracowników, ludzie, od których można się uczyć, pomoc w realizowaniu zadań w pracy, zaangażowanie w sprawy kościoła, we wspólnotę religijną, lojalność przyjaciół).

Uzyskane wyniki z jednej strony potwierdzają doniosłość założeń Teorii Zachowania Zasobów (COR) Hobfolla, z drugiej zaś empirycznie wspierają dotychczasowe analizy na gruncie polskich badań, wzbogacając je o konkretne narzędzia do pracy terapeutycznej [26-36]. Powyższe analizy stanowią jednocześnie empiryczne wsparcie dla badań nad rolą czynników, które wspomagają proces zdrowienia osób uzależnionych od alkoholu $[15,16,37-39]$.

Analiza wyników akcentuje fakt istnienia grupy osób uzależnionych od alkoholu, które nie skorzystają z terapii opartej na całkowitej abstynencji i nie osiągną tak sformułowanego celu terapeutycznego [38-40]. Biorąc pod uwagę koszty oraz wskaźnik efektywności tego typu leczenia, zasadne staje się poszukiwanie kryteriów wspomagających klasyfikację pacjentów do standardowego programu leczenia lub też do alternatywnej formy pomocy, jaką jest strategia redukcji szkód. Teza ta jest zgodna $\mathrm{z}$ dotychczasowymi postulatami wnoszonymi przez autorów propagujących pracę terapeutyczną opartą na redukcji szkód [41-44]. 
The gained results also indicate that the experience of a rise in resources in the initial phase of therapy significantly contributes to the rise in intensity of this factor during the subsequent months of therapy. The greater the sense of increasing resources felt by the dependent person in the period prior to treatment, the more often they noted a rise in resources also after 6 and 12 months following the start of treatment. A high intensity of perceived increase in resources is therefore especially important at the very start of therapy as it conditions this kind of experience during the course of treatment and as a consequence influences the maintaining of abstinence over a longer period of time. The presented conclusion confirms the results of other studies on COR relationships describing how people with available resources are more capable of gaining further resources and their initial increase leads to further gains $[6,9,14,24,25]$.

The limitation of the research project was above all the small number of subjects who took part in two phases. There were difficulties during the study concerning limited access to dependent persons following 6 months from the moment of treatment initiation.

In further studies, there ought to be above all a change in qualification procedure for participants in the project i.e. by gaining the subjects' initial agreement to later personal contact in their place of residence. A further limitation was that research material was collected mainly by the author. The involvement of a greater number of persons would help achieving more effective information gathering from respondents. The perspective of future studies ought to include above all the construction and evaluation of therapeutic programmes taking into account the results of studies. This will allow us to define what role in the scope of maintaining abstinence is played by the factors identified in this study. It would seem that of equal importance is the initiative of developing a questionnaire serving initial qualification of persons to a therapeutic programme based on the drinking limitation, that is on harm-reduction.

\section{- SUMmARY}

The decision to undertake therapy by a person who is dependent on alcohol is essentially a decision about change. Firstly, for it to have a chance of taking place and the person to even consider
Uzyskane rezultaty wskazują również, że doświadczanie wzrostu zasobów w początkowym etapie terapii istotnie wpływa na wzrost nasilenia tego czynnika podczas kolejnych miesięcy leczenia. Im większe poczucie zwiększania zasobów miała osoba uzależniona w okresie poprzedzającym leczenie, tym częściej spostrzegała wzrost zasobów zarówno po 6, jak i po 12 miesiącach od rozpoczęcia leczenia. Wysokie nasilenie spostrzeganego wzrostu zasobów jest więc niezmiernie istotne na samym początku terapii, ponieważ warunkuje tego rodzaju doświadczanie w trakcie trwania leczenia, a w konsekwencji wpływa na utrzymywanie abstynencji w dłuższym okresie. Przedstawiony wniosek potwierdza rezultaty innych badań dotyczących zależności COR, mówiącej o tym, że ludzie posiadający zasoby są bardziej zdolni do osiągania kolejnych zasobów, a ich początkowy wzrost pociąga za sobą dalsze $[6,9,14,24,25]$.

Ograniczeniem projektu badawczego była przede wszystkim niewielka liczba badanych, którzy uczestniczyli w jego dwóch etapach. Występujące trudności w trakcie prowadzonych badań dotyczyły ograniczonego dostępu do osób uzależnionych po upływie 6 miesięcy od momentu rozpoczęcia leczenia.

W dalszych badaniach należałoby przede wszystkim zmienić procedurę kwalifikacji osób do udziału w projekcie, m.in. przez uzyskanie wstępnej zgody badanego na późniejszy kontakt osobisty w miejscu jego zamieszkania. Kolejnym ograniczeniem projektu było zbieranie materiału badawczego w większości przez samego autora. Zaangażowanie większej liczby osób pomogłoby $\mathrm{w}$ bardziej efektywnym uzyskiwaniu informacji od respondentów. Perspektywa przyszłych badań powinna obejmować przede wszystkim konstrukcję i ewaluację programów terapeutycznych uwzględniających uzyskane wyniki badań. Pozwoli to określić, jaką rolę w zakresie utrzymywania abstynencji odgrywają czynniki wyłonione w tych badaniach. Równie ważną inicjatywą wydaje się opracowanie kwestionariusza służącego do wstępnej kwalifikacji osób do programu terapeutycznego opartego na ograniczaniu picia, tj. na redukcji szkód.

\section{- Podsumowanie}

Decyzja o podjęciu terapii przez osobę uzależnioną od alkoholu jest w swej istocie decyzją o zmianie. Po pierwsze, by miała ona szansę za- 
the possibility of change, it is essential that the person has available a basic number of resources. Second, for the change to be effective, it is essential that resources are gained. The obtained results are a new perspective in the current of research on the possibility of predicting abstinence $[26,27,39$, $42,45,46]$.

The research indicates the obstacles encountered by a therapist at work. The gaining of many resources is impossible during the course of normal therapy. Therefore, a change of therapeutic approach to persons dependent on alcohol from the level of psychological activity to that of systemic cooperation is necessary. istnieć i dana osoba zaczęła rozważać możliwość zmiany, konieczne jest posiadanie przez nią bazowej liczby zasobów. Po drugie, by zmiana okazała się skuteczna, niezbędne jest pozyskiwanie zasobów. Otrzymane rezultaty stanowią swoiste novum w nurcie badań nad możliwością przewidywania abstynencji [26, 27, 39, 42, 45, 46].

Badania wskazują na ograniczenia, z jakimi spotyka się terapeuta $\mathrm{w}$ swoim gabinecie. Pozyskanie wielu zasobów jest niemożliwe w trakcie „terapii gabinetowej”. Istnieje zatem konieczność zmiany podejścia terapeutycznego do osób uzależnionych od alkoholu - z poziomu oddziaływań psychologicznych na poziom współpracy systemowej.

\section{Conflict of interest/Konflikt interesów}

None declared./Nie występuje.

\section{Financial support/Finansowanie}

None declared./Nie zadeklarowano.

\section{Ethics/Etyka}

The work described in this article has been carried out in accordance with the Code of Ethics of the World Medical Association (Declaration of Helsinki) on medical research involving human subjects, EU Directive (210/63/EU) on protection of animals used for scientific purposes, Uniform Requirements for manuscripts submitted to biomedical journals and the ethical principles defined in the Farmington Consensus of 1997.

Treści przedstawione w pracy są zgodne z zasadami Deklaracji helsińskiej odnoszącymi się do badań z udziałem ludzi, dyrektywami UE dotyczącymi ochrony zwierząt używanych do celów naukowych, ujednoliconymi wymaganiami dla czasopism biomedycznych oraz z zasadami etycznymi określonymi w Porozumieniu z Farmington w 1997 roku.

\section{References/Piśmiennictwo}

1. Dudek B, Koniarek J, Szymczak W. Stres związany z pracą a teoria zachowania zasobów Stevana Hobfolla. Medycyna Pracy 2007; 58(4): 317-25.

2. Steuden S. Z psychologicznej problematyki zdrowia i choroby. In: Oleś P, Steuden J, Toczydłowski J (eds.). Jak świata mniej widzę. Zaburzenia widzenia a jakość życia. Lublin: Towarzystwo Naukowe KUL; 2002, p. 27-36.

3. Steuden S, Oleś P. Życie jako zadanie. Lublin: Wydawnictwo KUL; 2006.

4. Hobfoll SE. Conservation of Resources. A New Attempt at Conceptualizing Stress. Am Psychol 1989; 44(3): 513-24.

5. Hobfoll SE, Vinokur AD, Pierce PF. The Combined Stress of Family Life, Work, and War in Air Force Men and Women: A Test of Conservation of Resources Theory. Int J Stress Manag 2012; 19(3): 217-37.

6. Hobfoll SE, Blais RK, Stevens NR. Vets Prevail Online Intervention Reduces PTSD and Depression in Veterans with Mild-to-Moderate Symptoms. J Consult Clin Psychol 2015; 84(1): 31-42.

7. Ehrlich M, Harville E, Xiong X. Loss of Resources and Hurricane Experience as Predictors of Postpartum Depression among Women in Southern Louisiana. $J$ Womens Health 2010; 19(5): 877-84. 
8. Chen S, Westman M, Hobfoll SE. The Commerce and Crossover of Resources: Resource Conservation in the Service of Resilience. Stress Health 2015; 31(2): 95-105.

9. Hobfoll SE, Canetti-Nisim D. Exposure to Terrorism, Stress-Related Mental Health Symptoms, and Defensive Coping among Jews and Arabs in Israel. J Consult Clin Psychol 2006; 74(2): 207-18.

10. Hobfoll SE, Stevens NR, Zalta AK. Expanding the Science of Resilience: Conserving Resources in the Aid of Adaptation. Psychol Inq 2015; 26: 174-80.

11. Mellibruda J, Sobolewska-Mellibruda Z. Integracyjna psychoterapia uzależnień. Teoria i praktyka. Warszawa: IPZ; 2006.

12. Miniszewska J, Chodkiewicz J. Zmaganie się z przewlekłą chorobą somatyczną w świetle psychologicznej koncepcji stresu. Przeglad Lekarski 2013; 70(7): 448-53.

13. Ojedokun O, Idemudia E. Burnout among paramilitary personnel in Nigeria: a perspective from Conservation of Resources Theory. S Afr J Psychol 2014; 44(1): 106-17.

14. Hobfoll SE. Stres, kultura i społeczność. Psychologia i filozofia stresu. Gdańsk: GWP; 2006.

15. Gruszczyńska E, Kaczmarek M, Chodkiewicz J. Hitting rock bottom? Resource loss as a predictor of alcoholism treatment completion. Nord J Psychiatry 2016; 70: 351-7.

16. Modrzyński R. Abstynencja czy ograniczanie picia? Znaczenie zasobów w przewidywaniu abstynencji osób uzależnionych od alkoholu we wczesnej fazie zdrowienia. Warszawa: Difin; 2017.

17. Hobfoll SE. The Influence of Culture, Community, and the Nested-Self in the Stress Process: Advancing Conservation of Resources Theory. Appl Psychol Int Rev 2001; 50(3): 337-421.

18. Hobfoll SE. Social and Psychological Resources and Adaptation. Rev Gen Psychol 2002; 6(4): 307-24.

19. Neveu JP. Jailed resources: Conservation of resources theory as applied to burnout among prison guards. Journal of Organizational Behaviour 2007; 28: 21-42.

20. Alarcon GM, Edwards JM, Menke LE. Student Burnout and Engagement: A Test of the Conservation of Resources Theory. J Psychol 2011; 45(3): 211-27.

21. Gerhart JI, Canetti D, Hobfoll SE. Traumatic Stress in Overview: Definition, Context, Scope, and Long-Term Outcomes. In: Cherry KE (ed.). Coping with Disasters and Other Negative Life Events. Switzerland: Springer International Publishing; 2015, p. 3-24.

22. Hobfoll SE, Spielberger CD. Family Stress: Integrating Theory and Measurement. J Fam Psychol 1992; 6(2): 99-112.

23. Hobfoll SE, Tracy M, Galea S. The Impact of Resource Loss and Traumatic Growth on Probable PTSD and Depression Following Terrorist Attacks. J Trauma Stress 2006; 19(6): 867-78.

24. Ennis NE, Hobfoll SE, Schröder KE. Money doesn't Talk, It Swears: How Economic Stress and Resistance Resources Impact Inner-City Women's Depressive Mood. Am J Community Psychol 2000; 28(2): 149-73.

25. Curran M, Totenhagen C, Serido J. How Resources (or Lack Thereof) Influence Advice Seeking on Psychological Well-being and Marital Risk: Testing Pathways of the Lack of Financial Stability, Support, and Strain. J Adult Dev 2010; 17: 44-56.

26. Chodkiewicz J. Zapobieganie nawrotom w chorobie alkoholowej - przegląd piśmiennictwa. Psychiatria 2016; 3(3): 105-11.

27. Chodkiewicz J. Odbić się od dna? Rola jakości życia w przebiegu i efektach terapii osób uzależnionych od alkoholu. Łódź: Wydawnictwo Uniwersytetu Łódzkiego; 2012.

28. Bętkowska-Korpała B. Osobowościowe uwarunkowania dynamiki zdrowienia u osób uzależnionych od alkoholu. Kraków: Uniwersytet Jagielloński Collegium Medicum; 2013.

29. Cierpiałkowska L, Kubiak J. Co leczy w podstawowej terapii osób uzależnionych? Ter Uzależ Wspóluzależ 2010; 4: 5-9.

30. Bakuła A. Dlaczego łamią abstynencję? Świat Problemów [online] 2003; 10 [Accessed 19 December 2017]. http://www.psychologia.edu.pl/czytelnia/62-wiat-problemow/881-dlaczego-lamia-abstynencje.html.

31. Zwierzchowski D. Czynniki wpływające na proces zdrowienia w opinii osób uzależnionych od alkoholu. Ter Uzależ Wspótuzależ 2010; 5: 5-22. 
32. Nikodemska S. Demograficzny portret pacjenta cz. I. Ter Uzależ Wspótuzależ 1999; 4 [Accessed 19 December 2017]. http://www.psychologia.edu.pl/czytelnia/63-terapia-uzalenienia-i-wspouzalenienia/364-demograficzny-portret-pacjenta-cz-i.html.

33. Nikodemska S. Demograficzny portret pacjenta cz. II. Ter Uzależ Wspótuzależ 2000; 1 [Accessed 19 December 2017]. http://www.psychologia.edu.pl/czytelnia/63-terapia-uzalenienia-i-wspouzalenienia/301-demograficzny-portret-pacjenta-cz-ii.html.

34. Nikodemska S. Efekty terapii w różnego typu placówkach odwykowych. Ter Uzależ Wspóluzależ 2000; 1 [Accessed 19 December 2017]. http://www.psychologia.edu.pl/ czytelnia/63-terapia-uzalenienia-i-wspouzalenienia/638-efekty-terapii-w-roznego-typu-placowkach-odwykowych.html.

35. Nikodemska S. Stabilizacja rodzinna pacjentów uzależnionych. Świat Problemów 2000; 12 [Accessed 19 December 2017]. http://www.psychologia.edu.pl/czytelnia/62-wiatproblemow/641-stabilizacja-rodzinna-pacjentow-uzaleznionych.html.

36. Kucińska M, Mellibruda J. Program Analizy Przebiegu i Efektów Terapii Alkoholików (APETA) - koncepcja i dotychczasowy przebieg badań. Alkohol Narkom 1997; 3: 325-34.

37. Evren C, Cetin R, Durkaya M. Clinical factors associated with relapse in male alcohol dependents during six-month follow-up. Bulletin of Clinical Psychopharmacology 2010; 20(1): 14-21.

38. Hunter-Reel D, McCrady B, Hildebrandt T. Emphasizing interpersonal factors: an extension of the Witkiewitz and Marlatt relapse model. Addiction 2009; 104(8): 1281-90.

39. Nordfjaern T. Relapse patterns among patients with substance use disorder. J Subst Use 2011; 16(4): 313-29.

40. Woronowicz BT. Uzależnienia. Geneza, terapia, powrót do zdrowia. Warszawa: Parpamedia; 2009.

41. Sempruch-Malinowska K, Zygadło M. Redukcja szkód związanych z przyjmowaniem środków psychoaktywnych. In: Jabłoński P (ed.). Uzależnienie od narkotyków. Podręcznik dla terapeutów. Warszawa: Krajowe Biuro ds. Przeciwdziałania Narkomanii; 2012, p. 253-65.

42. Jakubczyk A, Wojnar M. Całkowita abstynencja czy redukcja szkód - różne strategie terapii uzależnienia od alkoholu w świetle badań i międzynarodowych zaleceń. Psychiatr Pol 2012; 46(3): 373-86.

43. Tatarsky A. Redukcja szkód w psychoterapii. Nowe podejście w leczeniu uzależnień od narkotyków i alkoholu. Warszawa: KB ds. PN; 2012.

44. Gordon SM, Sterling R, Siatkowski C. Impatient desire to drink as a predictor of relapse to alcohol use following treatment. Am J Addict 2006; 15: 242-5.

45. Berking M, Margraf M, Ebert D, Wupperman P, Hofmann SG, Junghanns K. Deficits in emotion-regulation skills predict alcohol use during and after cognitive-behavioral therapy for alcohol dependence. J Consul Clin Psychol 2011; 79(3): 307-18.

46. Moore TM, Seavey A, Ritter K, McNulty JK, Gordon KC, Stuart GL. Ecological momentary assessment of the effects of craving and affect on risk for relapse during substance abuse treatment. Psychol Addict Behav 2014; 28(2): 619-24. 